\title{
Wound Healing Properties of Selected Natural Products
}

\author{
Nurul ‘Izzah Ibrahim, Sok Kuan Wong $®$, Isa Naina Mohamed, Norazlina Mohamed $®$, \\ Kok-Yong Chin ${ }^{\circledR}$, Soelaiman Ima-Nirwana and Ahmad Nazrun Shuid *
}

Department of Pharmacology, Faculty of Medicine, Universiti Kebangsaan Malaysia Medical Centre, Jalan Yaacob Latif, Bandar Tun Razak, Cheras, Kuala Lumpur 56000, Malaysia; nurulizzah88@gmail.com (N.I.I.); jocylnwsk@gmail.com (S.K.W.); isanaina@yahoo.co.uk (I.N.M.); azlina@ppukm.ukm.edu.my (N.M.); gabrielchinky@gmail.com (K.-Y.C.); imasoel@ppukm.ukm.edu.my (S.I.-N.)

* Correspondence: anazrun@yahoo.com; Tel.: +60-3-9145-9576

Received: 23 September 2018; Accepted: 19 October 2018; Published: 25 October 2018

\begin{abstract}
Wound healing is a complex process of recovering the forms and functions of injured tissues. The process is tightly regulated by multiple growth factors and cytokines released at the wound site. Any alterations that disrupt the healing processes would worsen the tissue damage and prolong repair process. Various conditions may contribute to impaired wound healing, including infections, underlying diseases and medications. Numerous studies on the potential of natural products with anti-inflammatory, antioxidant, antibacterial and pro-collagen synthesis properties as wound healing agents have been performed. Their medicinal properties can be contributed by the content of bioactive phytochemical constituents such as alkaloids, essential oils, flavonoids, tannins, saponins, and phenolic compounds in the natural products. This review highlights the in vitro, in vivo and clinical studies on wound healing promotions by the selected natural products and the mechanisms involved.
\end{abstract}

Keywords: antibacterial; anti-inflammatory; antioxidant; collagen; polyphenols; skin

\section{Introduction}

Skin is the largest organ of the body which makes up the outer covering of the living body. It consists of multiple layers of the ectodermal tissues guarding the underlying muscles, bones, ligaments, and internal organs. It also provides protection against microbes, heat, light and injury [1,2]. A wound is created when an injury to the normal structure and function of the skin occurs [3]. Wound healing refers to the complex and multifactorial process in response to a disruption of the normal anatomical structure and function of a skin tissue. It is characterized by a series of events, that is, inflammation, cellular phase (granulation), narrowing of wound area (wound contraction), collagen deposition (collagen formation), epithelial covering (epithelialization), and scar remodeling (cicatrization). The smooth progression of all these events leads to a successful completion of wound healing, and restoration of the disrupted anatomical and functional state of the skin [4-6].

In general, wounds healing in an orderly complex process that consists of three overlapping phases; inflammatory reaction, proliferation, and remodeling. The inflammatory phase involves vascular responses characterized by exudation, blood coagulation and hemostasis. During this process, varieties of immune cells from the blood vessels are attracted to the wound lesion and secrete pro-inflammatory cytokines. The inflammatory cells, notably neutrophils, may produce large amounts of reactive oxygen species (ROS). The ROS are essential in protecting the body against developing infection but, when present in excess amount, can simultaneously damage the surrounding tissues. In the normal process of wound healing, a reduction of immune cells and inflammatory 
cytokines should occur within a few days after an injury, and at the same time, migrating keratinocytes, fibroblasts, and endothelial cells start to secrete various growth factors. Subsequently, during the proliferative phase, there is a formation of the epithelium to cover the wound surface with concomitant growth of granulation tissue to fill the space of wound. The formation of granulation tissue involves proliferation of fibroblasts, deposition of collagens and other extracellular matrices (ECM) and development of new blood vessels (angiogenesis). The collagen synthesis causes contraction of wound and reduction of the wound size. The temporal ECM is gradually converted into a mature scar. During this process, type III collagen, which is a typical constituent in the granulation tissue, is replaced by type I collagen, a predominant constituent in the normal human dermis. This remodeling process will restore tissue structural integrity and functional competence. The process of wound healing is tightly regulated by multiple growth factors and cytokines released at the wound site [7].

Acute or normal wound healing proceeds through the orderly overlapping processes, allowing for repair of skin function and integrity in coordinated manner in healthy individuals. A normal wound healing usually occurs in 7 to 10 days [8]. Any alterations that disrupt the timely controlled healing processes would extend tissue damage and prolong the repair process, subsequently contributing to chronic wound healing [7,9]. Thus, a chronic wound healing can be defined as a disruption of the normal healing pathway. It can be caused by the underlying disease processes (such as diabetes or cardiovascular disease), infections, medications (steroids) and old age. The completion of full-thickness chronic wound healing may take months to years [8].

Wound healing process can be facilitated by natural products with medicinal properties. Many studies on the wound healing properties of natural products with anti-inflammatory, antioxidant, antibacterial and pro-collagen synthesis actions have been conducted. Their medicinal properties might be contributed by the bioactive phytochemical constituents of the various chemical families such as alkaloids, essential oils, flavonoids, tannins, terpenoids, saponins, and phenolic compounds [10]. Each bioactive agent may have specific function on wound healing properties. For instance, saponins can enhance the synthesis of pro-collagen [11], while tannins and flavonoids have antiseptic and antibacterial activities [12]. These phytochemicals can modulate one or more phases of the wound healing process. Furthermore, they are easily absorbed by the superficial layers of the skin [3]. Due to these properties, natural products and their phytochemicals have important roles in wound healing and they are used in the design of new synthetic compounds for this purpose [13]. This review aims to highlight the use of selected natural products (including Curcuma longa, vitamin E, honey and sea cucumber) in promoting wound healing and their mechanisms. These natural products have been used extensively in wound care management with excellent outcomes. The pre-clinical and clinical evidence studies of these natural products are also discussed in this review.

\section{Curcuma longa}

Curcuma longa (C. longa) or its common name, turmeric, is a member of the ginger family (Zingiberaceae). C. longa has been used since antiquity as a dye and condiment. In Asian countries, it is consumed daily for centuries and no toxicity has not been reported [14]. However, prolonged feeding of curcumin has been associated with incidences of ulcers, hyperplasia and inflammation of the forestomach, cecum and colon in male rats [15]. The bright yellow color of $C$. longa is derived primarily from the fat-soluble, polyphenolic pigments known as curcuminoids. Curcumin (diferuloylmethane), the principal curcuminoid found in C. longa, is generally considered as its most active constituent. Other curcuminoids found in turmeric include bisdemethoxycurcumin and demethoxycurcumin [16].

Several biological activities of curcumin have been identified, including anti-inflammatory, anticarcinogenic, anti-infectious, antioxidant, anti-apoptotic and wound healing activities [6,17-21]. To date, many in vitro [22-24] and in vivo [25-27] studies have been conducted to elucidate the effects of curcumin on wound healing activities. Despite the extensive in vitro and in vivo studies on wound healing activities of curcumin, there is a major barrier for wider clinical applications which reduces its therapeutic activity. The hydrophobic nature and photosensitive property of curcumin are the 
drawbacks for oral administration and topical application respectively. Curcumin possesses very poor aqueous solubility, permeability and bioavailability and is classified as a Biopharmaceutics Classification System (BCS) class IV molecule [28]. To enhance its bioavailability, curcumin has been incorporated into different formulations using hydrogel, nanoparticles, micelles, hyaluronic/oleic acid-loaded and glucosylation of the hydrophobic molecule in pre-clinical studies (Table 1). Curcumin has shown potential as a wound healing agent.

In these studies, curcumin was applied to the animals via topical dressing or given orally, as curcumin alone or incorporated into different formulations. In the study by Rao et al. (2015), they tested the effects of curcuminoids (curcumin, tetrahydrocurcumin (THC), and glucosyl-THC) topically on cutaneous excision-punch wound rat model [29]. Tetrahydrocurcumin is a major in vivo colorless hydrogenated metabolite of curcumin, while glucosyl-THC is a product of glucosylation of the hydrophobic molecule. In the study, they have proven that at $2 \%$ concentration of the curcuminoids, glucosyl-THC showed the best result in wound healing, with complete healing at 21 days. This indicated that glucosylation of the hydrophobic molecule may improve the bioavailability and pharmacological activities of curcumin [30,31]. Apart from glucosylated curcumin, in a study by Mohanty et al. (2012), curcumin formulated into oleic acid polymeric bandage (COP) resulted into increased wound reduction and enhanced cell proliferation [32]. The use of COP enables sustained release of curcumin in solubilized form and the sustained availability of solubilized curcumin metabolites (sulfates and glucoronates) at the wound site, which may promote better healing.

Other than that, a study by El-Rafaie et al. (2015) showed that healing efficacy of hyaluronic acid-based nanocarrier gel core incorporating curcumin in burn wounds of rats [33]. While, a study by Sharma et al. (2018) showed that the conjugated curcumin with hyaluronic acid (HA)-treated animals had better healing as compared to treatment with HA-free curcumin and HA alone [34]. Dai et al. (2017) have optimized a carrier system that enhanced solubility and availability of curcumin by embedding it into gelatin-based electrospun nanofibrous mats [35]. The application of this curcumin/gelatin-blended nanofibrous mats (NMs) enhanced regenerative process in rat model of acute wounds and thus may provide a method for translating this ancient medicine for use in modern wound therapy. Studies have shown that combination of curcumin with chemicals that possess excellent water absorption and fluid affinity such as oleic acid, hyaluronic acid and gelatin, improved bioavailability of the poorly soluble curcumin and thus promote better wound healing. Jagetia and Rajanikant (2004) performed an intervention in vivo study by pre-treating healthy mice orally with $100 \mathrm{mg} / \mathrm{kg}$ of curcumin prior to whole body $\gamma$ radiation and induction of full-thickness wound. The pre-treatment with curcumin significantly enhanced the rate of wound contraction, decreased mean wound healing time, increased synthesis of collagen, hexosamine, DNA, and nitric oxide that was impaired due to radiation [36]. 
Table 1. The effects of curcumin on wound healing in animal studies.

\begin{tabular}{|c|c|c|c|c|}
\hline Wound Type & Animal Type & Intervention, Dose \& Route & Findings & Study \\
\hline \multirow{3}{*}{ Incisional wounds } & C57BL/6J male mice & $\begin{array}{l}\text { Curcumin }(0.2 \mathrm{mg} / \mathrm{mL}) \text { in Pluronic } \\
\text { F127 hydrogel }(20 \%) \text {, topical }\end{array}$ & $\begin{array}{l}\text { Fast wound closure with well-formed granulation tissue dominated by collagen } \\
\text { deposition and regenerating epithelium. }\end{array}$ & [25] \\
\hline & $\begin{array}{l}\text { Male Sprague-Dawley rats } \\
\text { induced with dexamethasone } \\
\text { intramuscularly }\end{array}$ & $\begin{array}{l}\text { Curcumin with } 0.1 \% \text { ointment in } \\
\text { polyethylene glycol base, topical }\end{array}$ & $\begin{array}{l}\text { Curcumin significantly accelerated healing of wounds by reductions in wound } \\
\text { width and gap length compared to controls. } \\
\text { Curcumin treatment resulted in enhanced expression of TGF- } \beta 1 \text { and TGF- } \beta \text { tIIrc } \\
\text { in both normal and impaired healing by immunohistochemistry assessment. } \\
\text { Macrophages in the wound bed showed an enhanced expression of TGF- } \beta 1 \\
\text { mRNA in curcumin-treated wounds as evidenced by in situ hybridization. }\end{array}$ & [26] \\
\hline & Male Sprague-Dawley rats & $\begin{array}{l}\text { Curcumin/gelatin-blended } \\
\text { nanofibrous mats (NMs), topical }\end{array}$ & $\begin{array}{l}\text { The wounds treated with NMs showed regenerative process via (a) mobilization } \\
\text { of wound site fibroblasts by activation of the Wnt signaling pathway, partly } \\
\text { mediated through Dickkopf-related protein-1; (b) persistent inhibition of the } \\
\text { inflammatory response through decreased expression of monocyte } \\
\text { chemoattractant protein-1 by fibroblasts. }\end{array}$ & [35] \\
\hline \multirow{7}{*}{ Excisional wounds } & \multirow{3}{*}{ Male Wistar rats } & $2 \%$ curcumin, topical & Incomplete but normal healing at 21 days of treatment & \multirow{3}{*}{ [29] } \\
\hline & & $2 \%, 3 \%$, and $5 \%$ THC, topical & $\begin{array}{l}\text { For } 2 \% \text { THC, progressive but incomplete healing was observed at } 21 \text { days } \\
\text { of treatment }\end{array}$ & \\
\hline & & $2 \%, 3 \%$, and $5 \%$ glucosyl-THC, topical & For $2 \%$ glucosyl-THC, complete healing of wounds at 21 days of treatment & \\
\hline & Sprague-Dawley male rats & $\begin{array}{l}\text { Curcumin loaded oleic acid based } \\
\text { polymeric (COP) } \\
\text { bandage, topical }\end{array}$ & $\begin{array}{l}\text { Increased wound reduction and enhanced cell proliferation in COP } \\
\text { bandage-treated groups. } \\
\text { Comparative acceleration in wound healing. } \\
\text { Western blotting and semi quantitative PCR analysis clearly indicate that COP } \\
\text { bandage can efficiently quench free radicals. }\end{array}$ & [32] \\
\hline & $\begin{array}{l}\text { Streptozotocin-induced diabetic } \\
\text { Swiss albino mice }\end{array}$ & $\begin{array}{l}\text { Curcumin conjugated to hyaluronic } \\
\text { acid (HA) } \\
\text { (HA-Cur), topical }\end{array}$ & $\begin{array}{l}\text { HA-Cur treated group showed well-formed granulation tissue rich in fibroblast, } \\
\text { collagen and re-epithelialization was almost complete. }\end{array}$ & [34] \\
\hline & $\begin{array}{l}\text { Whole-body } \gamma \text { irradiated Swiss } \\
\text { albino mice }\end{array}$ & $\begin{array}{l}\text { Curcumin suspended in } 0.5 \% \text { carboxy } \\
\text { methylcellulose (CMC), } 100 \mathrm{mg} / \mathrm{kg} \\
\text { orally before irradiation }\end{array}$ & $\begin{array}{l}\text { Pre-treatment with curcumin significantly enhanced the rate of wound } \\
\text { contraction, decreased mean wound healing time, increased synthesis of } \\
\text { collagen, hexosamine, DNA, and nitric oxide and improved fibroblast and } \\
\text { vascular densities. }\end{array}$ & [36] \\
\hline & $\begin{array}{l}\text { Streptozotocin-induced diabetic } \\
\text { male Wistar rats }\end{array}$ & $\begin{array}{l}400 \mu \mathrm{L} \text { of curcumin }(0.3 \%) \text { in PF-127 } \\
\text { hydrogel }(25 \%) \text {, topical }\end{array}$ & $\begin{array}{l}\text { Curcumin increased the wound contraction, levels of anti-inflammatory } \\
\text { cytokine (IL-10), antioxidant enzymes (SOD, CAT and GPx) and decreased } \\
\text { expressions of inflammatory cytokines/enzymes (TNF- } \alpha, \text { IL-1 } \beta \text { and MMP-9). } \\
\text { Histopathologically, the curcumin-treated wounds showed better granulation } \\
\text { tissue dominated by marked fibroblast proliferation and collagen deposition; } \\
\text { wounds were covered by thick regenerated epithelial layer. }\end{array}$ & [37] \\
\hline
\end{tabular}


Enhanced wound healing activities such as good epidermal regeneration, dense granulation tissue and improved collagen content were observed in animals with wound impairment induced by streptozotocin, dexamethasone and radiation [26,34,36,37]. In a study by Kant et al. (2014), curcumin incorporated with PF-127 hydrogel (25\%) was topically applied to impaired wound of diabetic model. The wound contraction rate and the expressions of inflammatory cytokines/enzymes were increased, indicating enhanced wound healing [37]. In addition, a recent study by Yen et al. (2018) has also reported accelerated wound healing using similar type of hydrogel with curcumin but with some modifications on the formulation applied topically to healthy C57BL/6J male mice [25].

The wound healing effects of curcumin may be contributed by its anti-oxidant and anti-inflammatory properties. Kant et al. (2014) showed that curcumin applied topically on skin wound showed decreased expressions of tumor necrosis factor-alpha (TNF- $\alpha$ ), interleukin-1 1 beta (IL-1 $\beta$ ) and matrix metalloproteinase-9 (MMP-9) [37]. Additionally, ROS is a crucial regulator of wound healing process and is required at low levels for defense against invading pathogens, and to mediate intracellular signaling [38-41]. However, excessive amounts are produced in wounded and inflamed tissue by NADPH oxidase, an enzyme complex, which is expressed at particular high levels by inflammatory cells [42,43]. Curcumin treatment was shown to decrease the production of ROS and increase cellular proliferation in accelerating wound healing [20]. Curcumin application on the wounded skin showed increased levels of anti-inflammatory cytokine including interleukin-10 (IL-10) and antioxidant enzymes that is, superoxide dismutase (SOD), catalase (CAT) and glutathione peroxidase (GPx) [37].

Transforming growth factor-beta (TGF- $\beta$ ) and nitric oxide (NO) are important in wound healing process. In previous study by Mani et al. (2002), curcumin embedded with polyethylene glycol base significantly accelerated wound healing and enhanced expression of TGF- $\beta 1$ and its receptors type I TGF- $\beta$ (tIrc) in both normal and impaired healing [26]. During wound repair, TGF- $\beta 1$ may stimulate epidermal keratinocytes to express integrins, which facilitate the migratory component of reepithelialisation [44]. The greater expression of TGF- $\beta 1$ in curcumin-treated wounds could therefore be a basis for the enhancement of healing by curcumin. Nitric oxide production is regulated by inducible nitric oxide synthase (iNOS) that is produced by infiltrating inflammatory cells. A study by Thornton et al. (1998) suggested that wound nitric oxide enhanced collagen accumulation [45]. Indeed, a study by Yen et al. (2018) revealed that the levels of collagen were significantly higher in curcumin-treated wounds than control group, resulting into increased wound tensile strength [25].

For an effective use of curcumin as wound healing agent, it can be incorporated into a patch for prolonged release of the substance. Apart from glucosylation, there may be other ways to chemically modify its structures to make it more water soluble. Cucurmin also has antimicrobial activity, hence it may be used in infected wounds. However, it is unclear about the bioavailability of curcumin through topical route and whether it will cause hypersensitivity. There are also aesthetics issues such as yellow staining of the skin and clothes and some might not like its smell. In summary, curcumin could be a promising therapeutic agent for wound healing via multiple biological actions such as regulating anti-oxidant and anti-inflammatory mediators as well as promoting collagen deposition at the wound site. As there are many pre-clinical studies using different formulations of curcumin to improve its bioavailability, further investigations are recommended to examine its effects in clinical trials.

\section{Vitamin $\mathrm{E}$}

Vitamin E consists of two major subfamilies, namely tocopherol and tocotrienol. Both tocopherol and tocotrienol exist in alpha $(\alpha)$, beta $(\beta)$, gamma $(\gamma)$, and delta $(\delta)$ forms, depending on the position of the methyl groups on the chromanol ring $[46,47]$. The main sources of vitamin $\mathrm{E}$ include wheat germ oil, wheat, rice bran, barley, oats, coconut, palm and annatto [46]. Since the discovery of vitamin $\mathrm{E}$ as a potent lipophilic anti-oxidant, anti-inflammation and platelet aggregation inhibitor [48], it has been regarded as a potential agent in treating burns, surgical wound and other wounds. Vitamin E acts as a reducing agent by scavenging free-radicals to prevent oxidative reaction that can cause tissue 
damage [49]. In an earlier in vivo study, Shukla et al. (1997) reported that wounding resulted in the loss of both enzymatic [SOD, GPx, CAT, glutathione-S-transferase (GST)] and non-enzymatic (ascorbic acid, vitamin E, and glutathione) antioxidants, which were partially or completely recovered following healing. Findings obtained from this study suggested the utilization of free radical scavengers to facilitate the self-healing of a wound [50].

Most preclinical studies reported promising wound healing properties of vitamin E using healthy murine, healthy swine, and diabetic murine models (Table 2). In these studies, vitamin E was administered to the animals via topical dressing, oral gavage or injections [intramuscularly (i.m.) or intraperitoneally (i.p.)]. Accelerated wound closure rate was detected in both genetically and chemically-induced diabetic rodents [51-55]. Vitamin E-related intervention facilitated the formations of new blood capillaries (angiogenesis), epithelium (epithelialization), tissue granulation, collagen fibers and dermis layers at the excisional and incisional wounds. In retrospect, Simon et al. (1994) found that pre-treatment of vitamin $\mathrm{E}$ via injection or dressing decreased the wound healing time for laser injury in healthy female Yorkshire pig by approximately one week compared to the negative control group [56]. In addition, a recent research fabricated a novel organic-inorganic dressing of copper-doped borate bioactive glass/poly(lactic-co-glycolic acid) loaded with vitamin E (3\%), which has shown effectiveness in healing skin defects in the healthy rats [57]. Raxofelast, a synthetic analogue of vitamin E, was also found to restore wound healing to nearly normal levels in diabetes-impaired wound in mice [58]. Another in vivo study reported paradoxical outcomes whereby the animals with a $4 \mathrm{~cm}^{2}$ full-thickness incision treated topically with $0.1435 \mathrm{~g}$ of test formulation (containing medium chain triglycerides, linoleic acid, vitamin A, vitamin E and soy lecithin) did not show any acceleration in the process of tissue healing. In fact, the exact dose of vitamin $E$ in the test solution used in this study was not mentioned [59].

Several human studies provided evidence that the interventions containing vitamin E (administered either orally or topically) conferred beneficial effects on wound healing. In a randomized, double-blind, placebo-controlled pilot study, a total of 32 children aged 2-15 years with thermal trauma [burn area more than $10 \%$ but less than $50 \%$ of total body surface area (TBSA)] were randomized into no supplementation or oral anti-oxidant supplementation groups. The anti-oxidant supplement consisted of a mixture of vitamin C (1.5 times upper intake level), vitamin E (1.35 times upper intake level) and zinc (2.0 times recommended dietary allowance). The findings showed that the supplemented group required less time to complete tissue repair in wounds [60]. In the subsequent year, a single-blinded prospective study was conducted to compare the pre- and post-surgery use of vitamin E (dose not mentioned) in the form of Lipoge ${ }^{\circledR}$ on surgical incisions in children underwent elective inguinal surgery $(n=428)$. Topical application of vitamin E before and after surgery significantly improved surgical wound healing with no cases of wound infection and no development of keloids in all the patients [61]. Recently, another prospective study evaluated the effects of silicone- $\alpha$-tocopherol acetate dressing (dose not mentioned) at skin graft donor sites in patients requiring split-thickness skin graft for any reconstructive purpose ( $n=60$, aged 9-82 years). Significant reductions in pain perception and total cost of treatment were observed following the intervention [62]. However, vitamin E seems to have no apparent effects in reducing scars. Researchers have conducted a prospective randomized, double-blind trial to assess the effects of $5 \%$ tocotrienol on hypertrophic scars in subjects with recently (less than 2 weeks) healed operational scars ( $\mathrm{n}=122$; aged 16-59 years). Topical application of the prescription twice a day had no significant effect on the scar appearance and vascularity after 4 months [63]. A report by Baumann and Spencer (1999) revealed that there was no improvement in the cosmetic appearance of scars with high incidence of contact dermatitis in patients underwent skin cancer removal surgery $(n=12)$ after treated with Aquaphor ${ }^{\circledR}$ mixed with two capsules of $\mathrm{d}-\alpha$-tocopheryl at a concentration of $320 \mathrm{IU} / \mathrm{g}$ [64]. 
The inflammation stage is the first event during the wound healing process. Neutrophils and macrophages are recruited to secrete inflammatory cytokines and ROS, thus providing the bacteriostatic effects against invading bacteria. Overwhelming inflammatory response and ROS production exceeding the capacity of the endogenous defense may lead to tissue damage, thus suggesting the pivotal role of inflammation and ROS modulation during wounding [65]. Previous studies indicated that vitamin E regulated oxidative stress [decreased 4-hydroxynoneal (4-HNE) and malondialdehyde (MDA) levels] and inflammation [reduced nuclear factor kappa-light-chain-enhancer of activated B cell (NF-kB), TNF- $\alpha$, and IL-1 $\beta$ ] in diabetic cutaneous wounds [53,54,58]. Vitamin E also increased the anti-oxidative enzymes such as SOD, GPx and CAT responsible for detoxifying ROS and oxidized macromolecules in wound tissues [52]. Indeed, vitamin E also possessed beneficial effects in the subsequent stages (proliferation and remodeling phases) of wound healing process by stimulating the formation of new blood vessel along with re-epithelialization, matrix deposition, and collagen synthesis $[51,52,57,58]$. Apart from orchestrating the wound healing process, vitamin $\mathrm{E}$ has been demonstrated to act synergistically with antibiotics (tigecycline or daptomycin) to exhibit anti-microbial effects in a healthy mouse model of wound infection caused by methicillin-resistant Staphylococcus aureus (MRSA). Vitamin E and antibiotic increased levels of natural killer cell cytotoxicity, wound repair markers, and leukocyte populations in mice $[66,67]$.

Vitamin $\mathrm{E}$ is lacking any clear mechanism apart from suppressing inflammation and oxidative stress. Therefore, more research is needed on tocotrienol. As a conclusion, vitamin E may be a potential therapeutic agent for wound healing via suppressing bacterial growth as well as excessive oxidative stress and inflammation. However, no appreciable effect of vitamin E on scar appearance has been reported. Further investigations are recommended to draw a better conclusion on the clinical utility for scar management. 
Table 2. The effects of vitamin E on wound healing in animal studies.

\begin{tabular}{|c|c|c|c|c|}
\hline Wound Type & Animal Type & Intervention, Dose \& Route & Findings & Study \\
\hline \multirow{3}{*}{ Excisional wounds } & STZ-induced diabetic rats & $\begin{array}{l}\alpha \text {-tocopherol or } \\
\operatorname{PVE}(200 \mathrm{mg} / \mathrm{kg} \text {, oral })\end{array}$ & $\begin{array}{l}\text { Wound area was smaller at day 10; total protein content, collagen content SOD, and } \\
\text { GPx activities were increased; MDA level was reduced; epidermis was well-formed } \\
\text { and differentiated; re-epithelialization was completed; collagen was well-aligned. }\end{array}$ & [52] \\
\hline & STZ-induced diabetic rats & Tocopherol ( $0.1 \mathrm{~g}$, topical $)$ & $\begin{array}{l}\text { Wound closure rate was increased; total protein content and collagen fibers were } \\
\text { increased; epithelialization was completed; epithelium was well-formed; } \\
\text { interdigitation between epithelium and dermis layers was increased. }\end{array}$ & [51] \\
\hline & $\begin{array}{l}\text { Alloxan-induced } \\
\text { diabetic mice }\end{array}$ & $\gamma$-tocopherol (35 mg/kg, oral) & $\begin{array}{l}\text { Wound closure rate was accelerated; levels of } 4-\mathrm{HNE}, \mathrm{NF}-\mathrm{kB}, \mathrm{TNF}-\alpha, \& \text { IL- } 1 \beta \text { were } \\
\text { reduced; CAT level was increased. }\end{array}$ & [53] \\
\hline \multirow{2}{*}{$\begin{array}{l}\text { Excisional wounds } \\
\text { inoculated with } \\
\text { MRSA }\end{array}$} & \multirow{2}{*}{$\mathrm{BALB} / \mathrm{c}$ mice } & $\begin{array}{l}\text { Vitamin } \mathrm{E}(60 \mathrm{mg} / \mathrm{kg} \text {, oral })+ \\
\text { tigecycline }(2 \mathrm{mg} / \mathrm{kg} \text {, i.p.) or } \\
\text { daptomycin }(7 \mathrm{mg} / \mathrm{kg} \text {, i.p.) }\end{array}$ & $\begin{array}{l}\text { Bacterial load was reduced; natural killer cell cytotoxicity and leukocyte } \\
\text { populations were increased. }\end{array}$ & [67] \\
\hline & & $\begin{array}{l}\text { Annatto tocotrienol ( } 50 \mathrm{or} 100 \mathrm{mg} / \mathrm{kg} \text {, } \\
\text { oral) + daptomycin }(7 \mathrm{mg} / \mathrm{kg} \text {, i.p.) }\end{array}$ & $\begin{array}{l}\text { Bacterial load was reduced; natural killer cell cytotoxicity and wound repair } \\
\text { markers were increased. }\end{array}$ & [66] \\
\hline \multirow{5}{*}{ Incisional wounds } & Sprague-Dawley rats & $\begin{array}{l}\text { Copper-doped borate bioactive } \\
\text { glass/poly(lactic-co-glycolic acid) } \\
\text { dressing loaded with vitamin E } \\
(3 \%, \text { topical })\end{array}$ & $\begin{array}{l}\text { Wound closure rate was faster; number and density of new vessels were increased; } \\
\text { new endothelium formed was longer; collagen deposition was thicker. }\end{array}$ & [57] \\
\hline & Wistar rats & $\begin{array}{l}\text { Medium chain triglycerides + linoleic } \\
\text { acid + vitamin A, vitamin E + soy } \\
\text { lecithin }(0.1435 \mathrm{~g} \text {, topical })\end{array}$ & No acceleration in the process of tissue repair & [59] \\
\hline & STZ-induced diabetic rats & $\alpha$-tocopherol $(200 \mathrm{mg} / \mathrm{kg}$, oral $)$ & $\begin{array}{l}\text { Rate of wound closure was accelerated; SOD, GPx, and CAT activities were } \\
\text { increased; MDA level was reduced }\end{array}$ & [54] \\
\hline & 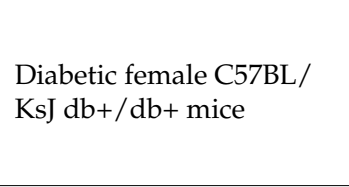 & $\begin{array}{l}\text { Raxofelast, a synthetic analogue of } \\
\text { vitamin E (15 mg/kg, i.p.) }\end{array}$ & $\begin{array}{l}\text { Impaired wound healing was improved; breaking strength and collagen content of } \\
\text { wound were higher; MDA level and MPO activity were decreased; } \\
\text { re-epithelialization was moderate to complete; granulation tissue was } \\
\text { well-organized; newly formed capillary vessels were observed; degree of infiltrated } \\
\text { inflammatory cells was minimal. }\end{array}$ & [58] \\
\hline & $\begin{array}{l}\text { Diabetic } \\
\text { C57BL/KsJm/Leptdb } \\
(d b / d b) \text { mice }\end{array}$ & $\begin{array}{l}\text { Mono-epoxy-tocotrienol- } \alpha(\mathrm{MeT} 3 \alpha) \\
(1 \mu \mathrm{mol})\end{array}$ & Closure of wound area was enhanced. & [55] \\
\hline $\begin{array}{l}\text { Skin irradiated } \\
\text { with argon and } \\
\text { copper-vapor laser }\end{array}$ & Yorkshire pig & $\begin{array}{l}\text { Vitamin E }\left(5 \mathrm{mg} / \mathrm{kg} \text {, i.m.; } 2 \mathrm{mg} / \mathrm{cm}^{2} \text {, }\right. \\
\text { topical) }\end{array}$ & Healing time for laser injury was reduced. & [56] \\
\hline
\end{tabular}




\section{Honey}

Honey is a yellowish-brown, sweet and viscous sugar solution gathered from nectar of flowers by bees and other insects. For the bees, the floral nectar is bio-transformed, deposited, dehydrated, stored and left in the honeycomb to ripen and mature [68]. It contains a mixture of carbohydrates (80-85\%), water $(15-17 \%)$, protein $(0.1-0.4 \%)$, ash $(0.2 \%)$ with small quantities of enzymes, vitamins, minerals, amino acids and organic acids $[69,70]$. The use of honey as a remedy to treat wounds has been practiced in folklore. This traditional belief has been scientifically proven by pre-clinical studies and clinical trials whereby honey accelerated the healing of a multitude of wound injuries, including burns, surgical wounds, infected surgical wounds, and malignant wounds. Findings from in vivo studies showed that honey-dressed wounds generally healed faster compared to the untreated wound (Table 3).

The characterization of wound lesions indicated by improvements in area of epithelialization, angiogenesis, breaking strength, tissue granulation, collagen deposition, and wound contraction after honey treatment had been performed previously. Some studies reported that the efficiency and efficacy of honey in wound healing was comparable to other usual wound care products such as Intrasite $\mathrm{Gel}^{\mathrm{TM}}$ [71], Alpha ${ }^{\circledR}$ ointment [72] and hydrocolloid dressing [71] but more superior than hydrofiber silver and hydrofiber dressings [73]. The aesthetic outcome of honey treatment was also reported, as thinner scars were formed at wound site of the animals [71]. However, Nakajima and colleagues pinpointed that Japanese honey (Acacia, Buckwheat flour or Chinese milk vetch) exerted limited benefit as some wounds were not completely healed after 14 days, although the wound area was decreased in the inflammatory phase [74]. In subsequent year, another study was conducted to investigate the effects of the combined use of Japanese honey (Manuka, Acacia or Chinese milk vetch) and hydrocolloid dressing on wound healing. The results showed that this intervention did not enhance cutaneous wound healing, characterized by larger wound size, delayed re-epithelialization and collagen deposition in the wounds [75].

To our knowledge, all honeys are not the same as it differs in the chemical compositions, biological properties and medicinal value depending on the environmental factors, geographic area, and nourishments collected from the plants [69]. The dose, frequency, duration, and route of administration for honey are also different in the animal experimentations. These variations may attribute to the distinct outcomes observed in these studies.

Additionally, the effects of honey in wound healing have been validated in several human studies with different types of wound. In a pilot study, a total of 10 patients with cutaneous wounds (aged 10-70 years) were enrolled. Honey showed beneficial effects in developing healthy granulation (pink-colored tissue as an indicator of healing), reducing burning sensation, and discoloration surrounding the skin at day 7 , as well as reducing pain, swelling, and tenderness at day 15 [76]. In a triple-blinded randomized prospective clinical trial involving 75 women with caesarean section [mean age: $27.70 \pm 4.97$ years (honey group), $26.57 \pm 4.88$ years (placebo group)], honey was found to reduce redness, edema, ecchymosis, discharge and approximation of wound edges (REEDA) score at day 7 and 14 [77]. Similar outcome was reported in nulliparous women with episiotomy incision ( $n=120$; aged 18-35 years) whereby honey significantly reduced the REEDA score. However, treatment with honey did not reduce pain intensity in episiotomy wounds [78]. The effects of honey on malignant wounds were also evaluated by Lund-Nielsen et al. (2011). In this randomized study, patients with advanced stage cancer and malignant wounds $(n=69$; age: 47-90 years) were recruited [79]. The patients experienced a decrease in wound size, malodor and an improvement of wound cleanliness over time after using the honey-coated bandage. There were no significant changes for exudation and wound pain during the intervention period [79]. Another randomized clinical trial was performed to assess the wound healing properties and cosmetic outcomes of honey on surgical wounds in female patients underwent an elective plastic surgery ( $n=52$; aged $34 \pm 3$ years). The findings showed that the application of honey dressing reduced mean width of the scar and led to a lower probability of developing surgical complications such as marked erythema, dehiscence and infection [80]. Besides, the effects of honey on burn wounds have been evaluated in several studies. In the first study, patients 
with partial thickness burns ( $<30 \%$ TBSA) and requiring tangential excision ( $\mathrm{n}=10$, age: $2-60$ years) were included and dressed with Tualang honey. The bacterial load on wound was significantly lowered on day 6 onwards, suggesting that Tualang honey might have bactericidal and bacteriostatic effects [81]. In the second study, $84 \%$ and $100 \%$ of patients with superficial thermal burns $(<40 \%$ TBSA) ( $n=100$; aged 3-70 years) showed satisfactory epithelialization in honey-dressed wounds after 7 and 21 days, respectively [82]. In patients with first and second degree of burns $(<50 \%$ TBSA) $(n=108$, aged 10-68 years), the duration of healing in honey-treated wounds was also shorter compared to silver sulfadiazine-treated wounds $[83,84]$. Overall, the positive outcomes of honey were consistently reported in the documented human studies.

The administration dose or amount of honey applied on wound was not mentioned in some of these studies. Only the anti-microbial activities of honey in wound were investigated. Evidence on other biological activities, particularly the immunomodulatory and anti-oxidative actions of honey, which have been proposed as the possible underlying mechanisms in wound healing enhancement are limited. The common characteristics of honey, including high sugar content (high osmolarity), high viscosity, low water content, and low $\mathrm{pH}$ (high acidity), provide a protective barrier against invading pathogens. Honey is not an appropriate medium for bacteria as it produces osmotic effect to dehydrate microbes thus hindering their growth. The ability of honey to produce hydrogen peroxide following dilution with water is another proposed reason for its bacteriostatic and bactericidal properties. This is with the exception of Manuka honey as it is a non-peroxide honey displaying anti-microbial effects [85]. Nonetheless, a variation in the anti-bacterial properties of honey was observed in laboratory and clinical studies. Data published by Khoo et al. (2010) showed that Tualang honey was superior in inhibiting the growth of Pseudomonas aeruginosa, but less effective in the control of Acinetobacter baumannii wounds as compared to hydrofiber silver and hydrofiber [73]. On the other hand, Tualang honey exhibited negligible effect in Klebsiella pneumonia-inoculated wound. Another report by Nasir et al. (2010) revealed that Tualang honey was not as effective as silver-based dressing for Gram-positive bacteria, such as Streptococcus spp., Staphylococcus aureus, and coagulase-negative S. aureus [81].

The immunomodulatory and anti-oxidative effects of honey have been previously established in in vitro wound healing model or other animal models. In vitro studies found that incubation of honey and monocytic cells stimulated the productions of TNF- $\alpha$, IL-6, and IL- $1 \beta$ from monocytes, thus speculating the therapeutic potential of honey in wound might be elicited through the stimulation of pro-inflammatory cytokines [86,87]. In contrast with the immunostimulatory effects, the anti-inflammatory properties of honey have also been elucidated. Honey has been shown to attenuate the nuclear translocation and activation of NF- $\mathrm{KB}$ with subsequent decrease in inflammatory mediators such as cyclooxygenase-2 (COX-2) and TNF- $\alpha$ [88]. Another study by Sell et al. (2012) indicated that honey modulated the release of pro- (TNF- $\alpha$ ) and anti-inflammatory cytokines (IL-10) as well as stimulated proliferation, collagen matrix production and migration of fibroblasts into in vitro wound healing model [89]. Moreover, honey has anti-oxidative ability to neutralize oxidative stress by increasing the levels of GPx, GSH, SOD, and NO as well as decreasing the levels of MDA, TNF- $\alpha$, IL- 6 and IL-1 $\beta$ in animals [90]. Taken together, it has been postulated that honey may be a potent immunomodulator (with both pro- and anti-inflammatory activities) and anti-oxidant at different stages of wound healing processes.

In conclusion, it is believed that honey may appear as an alternative and affordable approach for wound management via eradication of bacterial infection. Even though the anti-microbial efficacy of honey varies on different microorganisms, microbial resistance to honey has never been reported [91]. Honey is also less sticky to the wound base leading to easier wound dressing, has no allergic reaction and side effects $[73,92]$. Indeed, further scientific proof from both in vivo studies and clinical trials are appreciated to support the notion that honey is effective in enhancing wound healing via its immunomodulatory and anti-oxidative abilities. However, it is difficult to standardize honey composition due to its variety. There are also concerns of its high sugar content to diabetic patients, fake honey and sustainability of honey harvesting. 
Table 3. The effects of honey on wound healing in animal studies.

\begin{tabular}{|c|c|c|c|c|}
\hline Wound Type & Animal Type & Intervention, Dose \& Route & Findings & Study \\
\hline \multirow{11}{*}{ Excisional wounds } & \multirow{4}{*}{ Sprague-Dawley rats } & Gelam honey (topical) & Wound healed earlier; wounds exhibited less scab; formation of thin scar. & [71] \\
\hline & & Honey (topical) & Wound healed in 21 days; collagen deposition and neovascularization was increased & [72] \\
\hline & & $\begin{array}{l}\text { Pectin-honey hydrogel or Manuka } \\
\text { honey (topical) }\end{array}$ & $\begin{array}{l}\text { Wound area reduction rate was faster; entire surface of lesion was covered with new } \\
\text { epithelium; dermis was well-developed; mature fibrous tissue proliferation } \\
\text { was observed. }\end{array}$ & [93] \\
\hline & & Teucrium polium honey (topical) & $\begin{array}{l}\text { Healed wound area percentage was increased; re-epithelialization, granulation } \\
\text { tissue formation, collagen arrangement, fibrinoleukocytic exudates severity, } \\
\text { vasculature hyperemia or congestion, dermis organization and epidermal } \\
\text { appendage reappearance were improved }\end{array}$ & [94] \\
\hline & Swiss Wistar rats & Acacia honey ( $5 \%$ or $10 \%$, topical) & Period of epithelialization was reduced; wound contraction was increased. & [95] \\
\hline & $\begin{array}{l}\text { Albino N-Mary } \\
\text { Rats }\end{array}$ & $\begin{array}{l}\text { Natural honey }(10 \mathrm{~mL})+\text { zinc sulphate } \\
(36.3 \mathrm{mg}) \text { (topical) }\end{array}$ & $\begin{array}{l}\text { Tensile strength was increased; collagen fibers, re-epithelialization and } \\
\text { re-vascularization were increased. }\end{array}$ & [96] \\
\hline & Oryctolagus cuniculus rabbits & Natural honey (topical) & $\begin{array}{l}\text { Tensile strength of wounds, wound contraction, neovascularization, fibroplasias, } \\
\text { epithelialization, and formation of collagen were increased }\end{array}$ & [97] \\
\hline & New Zealand White rabbits & $\begin{array}{l}\text { Honey (chestnut, blossom, } \\
\text { or rhododendron) (topical) }\end{array}$ & $\begin{array}{l}\text { Formation of granulation tissue, epithelialization, angiogenesis, and fibroplasia } \\
\text { levels were increased on day } 7 .\end{array}$ & [98] \\
\hline & \multirow{3}{*}{$\mathrm{BALB} / \mathrm{cCrSlc}$ mice } & $\begin{array}{l}\text { Indonesia pure honey }(0.1 \mathrm{~mL} \text {, topical }) \\
\text { or Manuka honey }(0.1 \mathrm{~mL} \text {, topical })\end{array}$ & $\begin{array}{l}\text { Wound area was smaller; myofibroblasts and new blood capillaries were observed } \\
\text { on day } 3\end{array}$ & [71] \\
\hline & & $\begin{array}{l}\text { Japanese honey (Acacia, Buckwheat } \\
\text { flour, or Chinese milk vetch) } \\
(0.1 \mathrm{~mL} \text {, topical })\end{array}$ & $\begin{array}{l}\text { Wound size was reduced in inflammatory phase, increased in proliferative phase } \\
\text { and then decreased in proliferative phase; some wounds were not completely } \\
\text { covered with new epithelium. }\end{array}$ & [74] \\
\hline & & $\begin{array}{l}\text { Japanese honey (Manuka, Acacia, } \\
\text { Chinese milk vetch) }(0.1 \mathrm{~mL})+ \\
\text { hydrocolloid dressing (topical) }\end{array}$ & $\begin{array}{l}\text { Wound area was larger; numerous macrophages were observed; no significant } \\
\text { difference in TNF- } \alpha \text { and TGF- } \beta \text { levels; re-epithelialization and collagen deposition } \\
\text { were delayed. }\end{array}$ & [75] \\
\hline $\begin{array}{l}\text { Excisional wounds } \\
\text { inoculated with } \\
\text { MRSA }\end{array}$ & Wistar rats & $\begin{array}{l}\text { Melipona scutellaris honey } \\
\left(0.1 \mathrm{~mL} / \mathrm{cm}^{2}, \text { topical }\right)\end{array}$ & $\begin{array}{l}\text { Bacterial count was decreased; levels of TNF- } \alpha \text {, IL-1 } \beta \text {, and IL- } 6 \text { were increased; } \\
\text { density of healing parameters (collagen, leukocytes and fibroblasts) were higher. }\end{array}$ & [99] \\
\hline
\end{tabular}


Table 3. Cont

\begin{tabular}{|c|c|c|c|c|}
\hline Wound Type & Animal Type & Intervention, Dose \& Route & Findings & Study \\
\hline \multirow{5}{*}{ Incisional wounds } & Standardbred horses & Manuka honey (2 mL, topical) & Wound area was smaller; wounds healed faster. & [100] \\
\hline & Sprague-Dawley rats & Teucrium polium honey (topical) & $\begin{array}{l}\text { Healed wound area percentage was increased; re-epithelialization, granulation } \\
\text { tissue formation, collagen arrangement, fibrinoleukocytic exudates severity, } \\
\text { vasculature hyperemia or congestion, dermis organization and epidermal } \\
\text { appendage reappearance were improved }\end{array}$ & [94] \\
\hline & Swiss Wistar rats & Acacia honey ( $5 \%$ or $10 \%$, topical) & Breaking strength was increased. & [95] \\
\hline & \multirow{2}{*}{ Wistar rats } & Honey (topical) & $\begin{array}{l}\text { Wound area was decreased; there were more collagen fibers and fibroblasts in } \\
\text { honey-treated group. }\end{array}$ & [101] \\
\hline & & Honey + propolis (topical) & $\begin{array}{l}\text { Wound area was decreased; number of vessels, collagen, fibroblast and cellular } \\
\text { activity were increased. }\end{array}$ & [102] \\
\hline \multirow{4}{*}{ Burn wounds } & Wistar rats & $\begin{array}{l}\text { Honey, milk, and Aloe vera ointment } \\
(5 \% \text {, topical })\end{array}$ & $\begin{array}{l}\text { Wound area was decreased; thickness of the epidermis, fibroblast, and blood vessel } \\
\text { counts were increased; scar tissue was softer. }\end{array}$ & [103] \\
\hline & Swiss Wistar rats & Acacia honey ( $5 \%$ or $10 \%$, topical) & Period of epithelialization was reduced; wound contraction was increased. & [95] \\
\hline & \multirow{2}{*}{ Guinea pigs } & $\begin{array}{l}\text { Ulmo (Eucryphia cordifolia) honey } \\
\text { (topical) }\end{array}$ & $\begin{array}{l}\text { Eschar was shed earlier and diameter of wound was smaller at day 6-7; diameter of } \\
\text { wound decreased to } 50 \% \text { at day } 10 ; \text { no epidermal regeneration was observed; } \\
\text { an initial proliferative stage was observed with abundant cellularity, active } \\
\text { fibroblasts and neoformation of blood vessels in the superficial dermis. }\end{array}$ & \multirow{2}{*}{ [104] } \\
\hline & & $\begin{array}{l}\text { Ulmo (Eucryphia cordifolia) honey + } \\
\text { ascorbic acid (topical) }\end{array}$ & $\begin{array}{l}\text { Eschar was shed earlier and diameter of wound was smaller at day } 6 \text {; diameter of } \\
\text { wound decreased to } 50 \% \text { at day } 10 \text {; epidermis was generated; an advanced } \\
\text { proliferative stage was observed with numerous blood vessels and small capillaries } \\
\text { in the superficial dermis, the scar tissue zone presented a fibroblastic reaction, } \\
\text { proliferation of collagen fibers, dense connective tissue, and thin collagen fibers. }\end{array}$ & \\
\hline $\begin{array}{l}\text { Burn wounds } \\
\text { inoculated with } \\
\text { P. aeruginosa, } \\
\text { K. pneumonia, } \\
\text { or A. baumannii }\end{array}$ & Sprague-Dawley rats & Tualang honey $\left(0.1 \mathrm{~mL} / \mathrm{cm}^{2}\right.$, topical $)$ & $\begin{array}{l}\text { Wound size and bacterial count were reduced in P. aeruginosa-inoculated wounds; } \\
\text { wounds healed completely on day } 21 \text { in P. aeruginosa-and A. baumannii-inoculated } \\
\text { groups; no statistically significant anti-bacterial effects in K. pneumonia-infected } \\
\text { wounds. }\end{array}$ & {$[73,105]$} \\
\hline
\end{tabular}




\section{Sea Cucumbers}

Sea cucumbers are soft and cylindrical-bodied echinoderms that used their tentacles for feeding microscopic algae, absorbing nutrients from the organic matter [106,107]. They are commonly known as trepang (Indonesia), beche-de-mer (France), or gamat (Malaysia) are marine invertebrates which have been utilized as a culinary delicacy, particularly in some parts of Asia [108,109]. The Chinese regard sea cucumbers as the most nutritious and luxurious seafood. They are used to treat several conditions including constipation, problems related to the kidneys, and reproductive disorders. Sea cucumbers contain high protein levels, low sugar and fat content, but no cholesterol [110].

Sea cucumbers are unique for their capability to renew or regenerate themselves and to repair as well as to restore lost organs. Some of the species can also divide themselves into two halves and each half grows and survives as a new creature. There are approximately 1500 species of sea cucumbers worldwide with the greatest number found in the Asia Pacific Region. In Malaysia, there are almost 42 species of sea cucumbers identified and Stichopus species was the most harvested for their medicinal properties [111]. Among the identified species, Stichopus hermanni species commonly known as gamat emas was believed to be the most effective species to treat joint pain, wound injuries, and back pain traditionally.

Dried or extracted sea cucumbers are commercially marketed as sea cucumber extracts and are frequently blended with well-known herbs to produce medicinal products in the form of nutritional supplement, either in capsules or tablets, ointment, toothpaste, body lotion, and facial cleanser. The supplements can be taken orally while the ointments can be applied to the face, gum, mouth, hands, feet, and other body parts [112]. They are well recognized as tonic and traditional remedy especially in East and South-East Asia. The content of bioactive compounds extracted from different sea cucumber species, especially triterpene glycosides (saponins) [113], chondroitin sulphates [114], glycosaminoglycans [115], sulphated polysaccharides [116], sterols (glycosides and sulphates) [117], phenolics [118], peptides [119], cereberosides [120] and lectins [121] might contribute to medicinal benefits and health functions of sea cucumbers.

Sea cucumbers have long been recognized in the folk medicine due to their high nutritious value, as they could nourish the body, moisten the intestine, tonify kidney, as well as treat stomach ulcers, asthma, hypertension, rheumatism, pain, gout, asthma, eczema, hyperglycemia, hypertension and wound healing $[122,123]$. Several pre-clinical have validated the wound healing properties of sea cucumber. Findings from in vivo studies revealed that wounds treated with sea cucumber generally demonstrated enhanced healing compared to the untreated wounds in various types of animal models (Table 4).

In these studies, accelerated wound contraction rate was observed with topical application of several sea cucumber species extracts on wounds induced in animals [124-127]. The process of wound contraction is an imperative event in wound healing phase because it acts as a major contributor to the healing of a full thickness wound [128]. This was supported by a significant improvement in contraction rate of full thickness excisional wounds in rats treated with topically applied sea cucumber extracts [124,125].

Apart from direct topical application, Zohdi et al. (2011) reported a significant wound contraction rates for S. hermanii-based hydrogel wound dressing at day 21 and 28 post burn wound. However, no significant differences were detected at day 7 and 14 post burn wound. This may indicate that the novel cross-linked gamat hydrogel (S. hermanii) dressings act at later stage of wound healing phase, which might be associated with reservoir capacities of hydrogel for the delivery of "gamat" on the wounded skin. The development of a sustained and controlled release system would immobilize biologically active species for longer period in hydrogel matrices. This would substantially increase the utility of incorporated sea cucumber during tissue repair and effectively interact with the wounds, thus facilitating healing process at later stage [127]. In contrast, Subramaniam et al. (2013) showed that topical application of $S$. horrens exhibited significantly smaller wounds at day $4(p<0.001)$, but no significant change on days $8,12,16$ and 21 when compared to negative control $(p>0.05)$. This indicated 
that direct topical application of sea cucumber may enhance wound contraction at the initial period of wound healing [125]. However, in comparison with gamat-based hydrogel, the use of different species might contribute to the variations of wound contraction rate at different period.

In addition, the wound healing properties of another sea cucumber species, Stichopus choronotus could also be observed at the initial phase of wound healing. Mazliadiyana et al. (2017) reported that the intermediate dose, $0.5 \% w / w$ aqueous extract of $S$. Chloronotus emulsifying ointment mixture demonstrated the highest percentage of wound reduction compared to other groups $(0.1 \%, 1.0 \%$, positive and negative controls) from day 6 following wound creation. At optimum dose of $S$. Choronotus, healing of minor wound was significantly better than the gold standard (flavine-a yellow acridine dye with antiseptic property) [126]. According to Althunibat et al. (2009), aqueous extract of S. chloronotus showed superior antioxidant activity by approximately $80 \%$ compared to its organic extract [129]. Besides that, a study by Fredalina et al. (1999) on fatty acids composition of S. chloronotus showed higher content of docosahexaenoic acid (DHA) polyunsaturated fatty acids (PUFA) in aqueous extract compared to its organic extracts [130]. The marine-derived DHA PUFA may increase pro-inflammatory cytokine production at wound sites assisting to control infection and preparing tissue for further repair by enhancing phagocytic activity, stimulating keratinocyte migration at wound edges, fibroblast chemotaxis and proliferation, breakdown of extracellular matrix proteins and regulating the release of additional cytokines and growth factors [131,132]. The method of sea cucumber extraction is an important matter, as different methods of extraction may produce different percentage of bioactive compounds. This was supported in the study by Mariana et al. (2011), whereby direct topical application of $S$. badionotus methanolic extract showed no significant wound reduction compared to vancomycin on the healing of heat-burn wound inoculated with MRSA [133]. Another factor that may contribute to the successful healing properties is the use of aqueous extract with an emulsifying ointment, which will retain the treatment time of the water-based crude extracts. Hence, there might be an increased rate of wound reduction if the water-based crude extracts were applied locally with an oil base or cream.

Similar with the study by Mazliadiyana et al. (2017) [126], Arundina et al. (2015) reported that S. hermanii promoted the initial phase of wound healing of traumatic ulcer in rats [134]. In this study, the treatment was applied one time to ulcer and the rats were sacrificed on the 4th day to examine the number of lymphocytes. The intermediate dose of $40 \%$ aqueous extract of $S$. hermanii showed the largest number of lymphocytes, compared to other groups ( $20 \%, 80 \%$ and controls). To contradict, the highest dose ( $80 \%$ aqueous extract) of $S$. hermanii had lower number of lymphocytes [134]. Thus, appropriate dose should be applied, as different concentrations of extract may act differently. Lymphocytes play an important role during inflammation by releasing lymphokines which affect the number of other inflammatory cells. One of the lymphokines produced is interleukin-2 (IL-2), which can bind to heparan sulphate and help the proliferation process of T-lymphocytes. T-lymphocytes will then secrete TGF- $\beta$, stimulating fibroblast proliferation which plays a role on wound healing [135].

As being discussed, the mechanisms that might contribute to the wound healing property of sea cucumber includes anti-inflammatory [127] and antibacterial properties [133]. The anti-inflammatory effect of sea cucumbers in clinical settings was studied by Haryanto et al. (2017) [136]. In this prospective observational study, sea cucumbers incorporated into Carbopol ${ }^{\circledR}$ gel base were applied topically to diabetic foot ulcer patients for 12 weeks. The results showed significant differences in the TNF- $\alpha$ level between weeks 0 versus 8,0 versus 10 , and 0 versus 12 in the sea cucumber group $(p=0.005, p=0.006$, and $p=0.010)$ respectively. The content of saponin in sea cucumber extract may prevent the lipopolysaccharide-induced production of TNF- $\alpha$ by NF- $\mathrm{kB}$. NF- $\mathrm{kB}$ is a transcription factor that regulates the transcription of many genes associated with inflammation [137]. Moreover, the major fatty acids in sea cucumber; eicosapentaenoic acid (EPA) and DHA may stimulate the production of resolvins and protectins (anti-inflammatory mediators) through cyclooxygenase (COX-2) and lipoxygenase (5-LOX) pathways. Resolvins primarily inhibit IL-1 $\beta$ production, whereas protectin inhibits TNF and IL-1 $\beta$ production [138]. 
Table 4. The effects of sea cucumber on wound healing in animal studies.

\begin{tabular}{|c|c|c|c|c|}
\hline Wound Type & Animal Type & Intervention: Species, Route & Findings & Study \\
\hline \multirow[t]{3}{*}{ Excisional wounds } & Female Sprague Dawley rats & $\begin{array}{l}\text { Total sulphated glycosaminoglycan } \\
\text { from S. hermanni and S. Vastus, topical }\end{array}$ & $\begin{array}{l}\text { The contraction rate of wounds treated with total glycosaminoglycan from } \\
\text { S. hermanni and S. Vastus showed significant }(p<0.05) \text { improvement } \\
\text { compared to control group }\end{array}$ & [124] \\
\hline & $\begin{array}{l}\text { Either gender of Albino } \\
\text { Wistar rats }\end{array}$ & $\begin{array}{l}\text { S. horrens processed oil extract } \\
\text { twice daily for consecutive } 21 \text { days, } \\
\text { topical }\end{array}$ & $\begin{array}{l}\text { At day } 4, S \text {. horrens treated group exhibited significantly smaller wounds compared } \\
\text { to the negative control }(p<0.001) \\
\text { On days } 8,12,16 \text { and } 21 ; \text { S. horrens treated group and controls showed no significant } \\
\text { change in the wound contraction. }\end{array}$ & [125] \\
\hline & Male Sprague Dawley rats & $\begin{array}{l}\text { S. chloronotus at } 0.1 \%, 0.5 \% \text {, and } 1.0 \% \\
w / w \text { mixed with emulsifying ointment } \\
\text { once a day for } 10 \text { days, topical }\end{array}$ & $\begin{array}{l}\text { S. chloronotus treated group demonstrated a reduction in wound more rapidly } \\
\text { compared to other groups starting on day } 6 . \\
\text { On the } 6 \text { th post-wound day, S. chloronotus } 0.5 \% \text { demonstrated a significant wound } \\
\text { reduction compared to all other groups }(p<0.05) \text {. }\end{array}$ & [126] \\
\hline Burn wounds & Male Sprague-Dawley rats & $\begin{array}{l}\text { S. hermanii Hydrogel dressing } \\
\text { followed by OpSite }{ }^{\circledR} \text { film dressing } \\
\text { as secondary dressing, Topical }\end{array}$ & $\begin{array}{l}\text { At days 7, 14; No significant differences were observed in the measurement of } \\
\text { wound contraction between all experimental groups. } \\
\text { At days 21, 28; gamat hydrogel significantly increased wound contraction rates. } \\
\text { The mRNA levels for pro-inflammatory cytokines (IL-1a, IL-1b, and IL-6) in wounds } \\
\text { treated with gamat hydrogel were maintained at low levels throughout the healing } \\
\text { process as compared to other groups. } \\
\text { Histologically, advanced healing was observed; early re-epithelialization with } \\
\text { proliferating and migrating keratinocytes projected toward the center of the wound. }\end{array}$ & [127] \\
\hline $\begin{array}{l}\text { Heat-burn wound } \\
\text { inoculated with } \\
\text { MRSA }\end{array}$ & Male Sprague-Dawley rats & $\begin{array}{l}30 \mu \mathrm{g} / \mathrm{mL} \text { S. badionotus methanol } \\
\text { extract applied topically twice daily. }\end{array}$ & $\begin{array}{l}\text { The wound reduction measurement of } S \text {. badionotus showed no significant different } \\
\text { with vancomycin. }\end{array}$ & [133] \\
\hline $\begin{array}{l}\text { Traumatic ulcer } \\
\text { induced with } \\
\text { heated burnisher }\end{array}$ & Male Wistar rats. & $\begin{array}{l}20 \%, 40 \% \text { and } 80 \% \text { of } S . \text { hermanii } \\
\text { prepared as gel with polyethylene } \\
\text { glycol (PEG) } 400 \text { and } 4000 \text { solvent, } \\
\text { applied one time to ulcer }(0.1 \mathrm{mg})\end{array}$ & $\begin{array}{l}40 \% \text { S. hermanii treated group showed the biggest number of lymphocytes, while the } \\
80 \% \text { S. hermanii extract showed decreased number of lymphocytes. }\end{array}$ & [134] \\
\hline
\end{tabular}


As for antibacterial property of sea cucumber, Mariana et al. (2011) concluded that sea cucumber crude extract has potential to become an alternative resource for anti-MRSA drugs [133]. Apart from that, sea cucumber also possesses antioxidant property that can scavenge free radicals, whereby the presence of excessive free radicals is associated with impaired wound healing. The antioxidant activity of sea cucumber species; Bohadschia mamorata vitiensis, S. variegatus Semper, and S. badionotus Selenka might be contributed by the content of coelomic fluid, as reported by Hawa et al. (1999) [139]. Additionally, Althunibat et al. (2009) reported high antioxidant activities of three sea cucumber species, Holothuria scabra, Holothuria leucospilota and S. chloronotus at $77.46 \%, 64.03 \%$ and $80.58 \%$ respectively, against linoleic acid free radical [129]. In addition, the antioxidant activities of Atlantic sea cucumber, Cucumaria frondosa, might be attributed to its phenolic content, particularly flavonoids which act against oxidative reactions [118]. However, studies on the antioxidant effects of sea cucumber on wound healing are still lacking. Previous studies had focused only on the anti-inflammatory and antibacterial activities of sea cucumber on wound healing $[127,133,136]$. Thus, to elucidate the antioxidant property of sea cucumber on wound healing, further studies should be performed. Additionally, other biological activities of sea cucumbers on wound healing should be explored. However, harvesting sea cucumber for extraction is not sustainable. Therefore, identification of active compounds and upscaling the production are needed.

\section{The Advancements of Delivery System for the Selected Natural Products}

There are several advancements in the delivery system which maximize the therapeutic benefits of natural products, including hydrogel, scaffolds, conjugates, hydrocolloids, foam, nanoand micro-particles $[140,141]$. This review focused on hydrogel, particles, polymeric bandage, and conjugates. These delivery systems have different mechanisms of action in promoting wound healing properties. For instance, hydrogels, which are the water-based gels have a gentle and effective debriding and desloughing actions by rehydrating necrotic tissue and removing it without damaging nearby healthy tissues [141]. Conjugation with biomaterials that possess good viscoelastic, hydrophilic properties and lower molecular weight such as hyaluronic acid (HA) have been reported to stimulate angiogenesis, induce inflammation, regulate cell adhesion and promote proliferation of keratinocytes and fibroblasts [34]. In addition, the use of particles (micro or nano) may provide slow and sustained release of active compounds to wounds, enabling reduction in dose and frequency of dressing on wound.

\section{Conclusions}

Successful wound healing is important for the quality of life of the patients. This review highlighted several natural products with bactericidal, immunomodulating and wound healing activities. These products are derived from floral and faunal sources commonly found in the tropical regions. Most of these agents have been used since antiquity for wound healing. Although many in vivo and in vitro studies have proven their effectiveness in wound healing, documented clinical trials are still lacking and need to be conducted more to ensure the safety and effectiveness in human application. The current challenge lies on identification of the active compounds responsible for their wound healing properties and the mechanism involved. Upscaling the production of these compounds needs to be studied as the demand of wound healing agents is high. Management of wound contracture, exudates and bacterial control are still the major challenges in wound healing. Wound contraction is a natural mechanism for the closure of open wound in healing process; however, excessive wound contraction leads to physical deformity, functional limitations and disability. Most of the wound dressings do not possess the capabilities to absorb thick and viscous exudates from wound. With the advent of multi-resistant bacteria, agents to enhance wound healing and prevent breaching of bacteria to the body system are also particularly relevant. Therefore, further investigations could focus on evaluating the ability of natural products in wound contraction control, exudates management and prevention of infections effectively at the wound sites. 
Author Contributions: N.I.I., S.K.W designed and wrote the manuscript, I.N.M, N.M., S.I.-N. involved in conception and design of the manuscript, K.-Y.C. critically revised the manuscript, A.N.S. involved in acquisition of funding, conception and design and revised the manuscript. All authors read and approved the final manuscript.

Funding: The authors would like to thank the Universiti Kebangsaan Malaysia (UKM) for the grant (MI-2017-005).

Conflicts of Interest: The authors confirm that this article content has no conflicts of interest.

\section{References}

1. Kumar, B.; Vijayakumar, M.; Govindarajan, R.; Pushpangadan, P. Ethnopharmacological approaches to wound healing-Exploring medicinal plants of India. J. Ethnopharmacol. 2007, 114, 103-113. [CrossRef] [PubMed]

2. Enoch, S.; Leaper, D.J. Basic science of wound healing. Surgery 2008, 26, 31-37.

3. Tsala, D.E.; Amadou, D.; Habtemariam, S. Natural wound healing and bioactive natural products. Phytopharmacology 2013, 4, 532-560.

4. Maklebust, J.; Sieggreen, M. Anatomy and Physiology of Skin. In Pressure Ulcers Guidelines for Prevention and Management, 2nd ed.; Springhouse Corporation: Springhouse, PA, USA, 2005.

5. Martin, P. Wound healing-Aiming for perfect skin regeneration. Science 1997, 276, 75-81. [CrossRef] [PubMed]

6. Gopinath, D.; Ahmed, M.R.; Gomathi, K.; Chitra, K.; Sehgal, P.K.; Jayakumar, R. Dermal wound healing processes with curcumin incorporated collagen films. Biomaterials 2004, 25, 1911-1917. [CrossRef]

7. Kurahashi, T.; Fujii, J. Roles of Antioxidative Enzymes in Wound Healing. J. Dev. Biol. 2015, 3, 57-70. [CrossRef]

8. Baranoski, S.; Ayello, E.A. Wound Care Essentials: Practice Principles; Lippincott Williams \& Wilkins: Philadelphia, PA, USA, 2008.

9. Li, J.; Chen, J.; Kirsner, R. Pathophysiology of acute wound healing. Clin. Dermatol. 2007, 25, 9-18. [CrossRef] [PubMed]

10. Thakur, R.; Jain, N.; Pathak, R.; Sandhu, S.S. Practices in Wound Healing Studies of Plants. Evid.-Based Complement. Altern. Med. 2011, 2011, 438056. [CrossRef] [PubMed]

11. Chandel, R.S.; Rastogi, R.P. Triterpenoid saponins and sapogenins: 1973-1978. Phytochemistry 1980, 19, 1889-1908. [CrossRef]

12. Harbone, J.B. Phytochemical Methods: A Guide to Modern Techniques of Plants Analysis; Fakenham Press Limited: New York, NY, USA, 1973.

13. Biswas, T.K.; Mukherjee, B. Plant medicines of Indian origin for wound healing activity: A review. Int. J. Low. Extrem. Wounds 2003, 2, 25-39. [CrossRef] [PubMed]

14. Ammon, H.P.; Wahl, M.A. Pharmacology of Curcuma longa. Planta Med. 1991, 57, 1-7. [CrossRef] [PubMed]

15. Burgos-Morón, E.; Calderón-Montaño, J.M.; Salvador, J.; Robles, A.; López-Lázaro, M. The dark side of curcumin. Int. J. Cancer 2010, 126, 1771-1775. [CrossRef] [PubMed]

16. Akram, M.; Shahab-Uddin Afzal, A.; Khan, U.; Abdul, H.; Mohiuddin, E.; Asif, M. Curcuma longa and curcumin: A review article. Rom. J. Biol. Plant Biol. 2010, 55, 65-70.

17. Ramsewak, R.S.; DeWitt, D.L.; Nair, M.G. Cytotoxicity, antioxidant and anti-inflammatory activities of curcumins I-III from Curcuma longa. Phytomedicine 2000, 7, 303-308. [CrossRef]

18. Phan, T.T.; See, P.; Lee, S.T.; Chan, S.Y. Protective effects of curcumin against oxidative damage on skin cells in vitro: Its implication for wound healing. J. Trauma 2001, 51, 927-931. [CrossRef] [PubMed]

19. Chen, J.; Tang, X.Q.; Zhi, J.L.; Cui, Y.; Yu, H.M.; Tang, E.H.; Sun, S.N.; Feng, J.Q.; Chen, P.X. Curcumin protects PC12 cells against 1-methyl-4-phenylpyridinium ion-induced apoptosis by bcl-2-mitochondria-ROS-iNOS pathway. Apoptosis 2006, 11, 943-953. [CrossRef] [PubMed]

20. Panchatcharam, M.; Miriyala, S.; Gayathri, V.S.; Suguna, L. Curcumin improves wound healing by modulating collagen and decreasing reactive oxygen species. Mol. Cell. Biochem. 2006, 290, 87-96. [CrossRef] [PubMed]

21. Yucel, A.F.; Kanter, M.; Pergel, A.; Erboga, M.; Guzel, A. The role of curcumin on intestinal oxidative stress, cell proliferation and apoptosis after ischemia/reperfusion injury in rats. J. Mol. Histol. 2011, 42, 579-587. [CrossRef] [PubMed] 
22. Madhyastha, R.; Madhyastha, H.; Nakajima, Y.; Omura, S.; Maruyama, M. Curcumin facilitates fibrinolysis and cellular migration during wound healing by modulating urokinase plasminogen activator expression. Pathophysiol. Haemost. Thromb. 2010, 37, 59-66. [CrossRef] [PubMed]

23. Demirovic, D.; Rattan, S.I. Curcumin induces stress response and hormetically modulates wound healing ability of human skin fibroblasts undergoing ageing in vitro. Biogerontology 2011, 12, 437-444. [CrossRef] [PubMed]

24. Venkatasubbu, G.D.; Anusuya, T. Investigation on Curcumin nanocomposite for wound dressing. Int. J. Biol. Macromol. 2017, 98, 366-378. [CrossRef] [PubMed]

25. Yen, Y.H.; Pu, C.M.; Liu, C.W.; Chen, Y.C.; Chen, Y.C.; Liang, C.J.; Hsieh, J.H.; Huang, H.F.; Chen, Y.L. Curcumin accelerates cutaneous wound healing via multiple biological actions: The involvement of TNF-alpha, MMP-9, alpha-SMA, and collagen. Int. Wound J. 2018, 15, 605-617. [CrossRef] [PubMed]

26. Mani, H.; Sidhu, G.S.; Kumari, R.; Gaddipati, J.P.; Seth, P.; Maheshwari, R.K. Curcumin differentially regulates TGF-beta1, its receptors and nitric oxide synthase during impaired wound healing. Biofactors 2002, 16, 29-43. [CrossRef] [PubMed]

27. Sidhu, G.S.; Man, H.; Gaddipati, J.P.; Singh, A.K.; Seth, P.; Banaudha, K.K.; Patnaik, G.K.; Maheshwari, R.K. Curcumin enhances wound healing in streptozotocin induced diabetic rats and genetically diabetic mice. Wound Repair Regen. 1999, 7, 362-374. [CrossRef] [PubMed]

28. Wahlang, B.; Pawar, Y.B.; Bansal, A.K. Identification of permeability-related hurdles in oral delivery of curcumin using the Caco-2 cell model. Eur. J. Pharm. Biopharm. 2011, 77, 275-282. [CrossRef] [PubMed]

29. Bhaskar Rao, A.; Prasad, E.; Deepthi, S.S.; Haritha, V.; Ramakrishna, S.; Madhusudan, K.; Surekha, M.V.; Rao, Y.S. Wound healing: A new perspective on glucosylated tetrahydrocurcumin. Drug Des. Dev. Thera. 2015, 9, 3579-3588. [CrossRef] [PubMed]

30. Anand, P.; Kunnumakkara, A.B.; Newman, R.A.; Aggarwal, B.B. Bioavailability of curcumin: Problems and promises. Mol. Pharm. 2007, 4, 807-818. [CrossRef] [PubMed]

31. Shahani, K.; Panyam, J. Highly loaded, sustained-release microparticles of curcumin for chemoprevention. J. Pharm. Sci. 2011, 100, 2599-2609. [CrossRef] [PubMed]

32. Mohanty, C.; Das, M.; Sahoo, S.K. Sustained wound healing activity of curcumin loaded oleic acid based polymeric bandage in a rat model. Mol. Pharm. 2012, 9, 2801-2811. [CrossRef] [PubMed]

33. El-Refaie, W.M.; Elnaggar, Y.S.; El-Massik, M.A.; Abdallah, O.Y. Novel curcumin-loaded gel-core hyaluosomes with promising burn-wound healing potential: Development, in-vitro appraisal and in-vivo studies. Int. J. Pharm. 2015, 486, 88-98. [CrossRef] [PubMed]

34. Sharma, M.; Sahu, K.; Singh, S.P.; Jain, B. Wound healing activity of curcumin conjugated to hyaluronic acid: In vitro and in vivo evaluation. Artif. Cells Nanomed. Biotechnol. 2018, 46, 1009-1017. [CrossRef] [PubMed]

35. Dai, X.; Liu, J.; Zheng, H.; Wichmann, J.; Hopfner, U.; Sudhop, S.; Prein, C.; Shen, Y.; Machens, H.-G.; Schilling, A.F. Nano-formulated curcumin accelerates acute wound healing through Dkk-1-mediated fibroblast mobilization and MCP-1-mediated anti-inflammation. NPG Asia Mater. 2017, 9, e368. [CrossRef]

36. Jagetia, G.C.; Rajanikant, G.K. Role of curcumin, a naturally occurring phenolic compound of turmeric in accelerating the repair of excision wound, in mice whole-body exposed to various doses of gamma-radiation. J. Surg. Res. 2004, 120, 127-138. [CrossRef] [PubMed]

37. Kant, V.; Gopal, A.; Pathak, N.N.; Kumar, P.; Tandan, S.K.; Kumar, D. Antioxidant and anti-inflammatory potential of curcumin accelerated the cutaneous wound healing in streptozotocin-induced diabetic rats. Int. Immunopharmacol. 2014, 20, 322-330. [CrossRef] [PubMed]

38. Clark, R.A.F. Wound Repair: Overview and General Considerations; The Molecular, Cellular Biology of Wound Repair, Plenum Press: New York, NY, USA, 1996.

39. Wlaschek, M.; Scharffetter-Kochanek, K. Oxidative stress in chronic venous leg ulcers. Wound Repair Regen. 2005, 13, 452-461. [CrossRef] [PubMed]

40. D'Autreaux, B.; Toledano, M.B. ROS as signalling molecules: Mechanisms that generate specificity in ROS homeostasis. Nat. Rev. Mol. Cell Biol. 2007, 8, 813-824. [CrossRef] [PubMed]

41. Sen, C.K.; Roy, S. Redox signals in wound healing. Biochim. Biophys. Acta 2008, 1780, 1348-1361. [CrossRef] [PubMed]

42. Darr, D.; Fridovich, I. Free radicals in cutaneous biology. J. Investig. Dermatol. 1994, 102, 671-675. [CrossRef] [PubMed] 
43. Bedard, K.; Krause, K.H. The NOX family of ROS-generating NADPH oxidases: Physiology and pathophysiology. Physiol. Rev. 2007, 87, 245-313. [CrossRef] [PubMed]

44. Gailit, J.; Welch, M.P.; Clark, R.A. TGF-beta 1 stimulates expression of keratinocyte integrins during re-epithelialization of cutaneous wounds. J. Investig. Dermatol. 1994, 103, 221-227. [CrossRef] [PubMed]

45. Thornton, F.J.; Schäffer, M.R.; Witte, M.B.; Moldawer, L.L.; MacKay, S.L.; Abouhamze, A.; Tannahill, C.L.; Barbul, A. Enhanced collagen accumulation following direct transfection of the inducible nitric oxide synthase gene in cutaneous wounds. Biochem. Biophys. Res. Commun. 1998, 246, 654-659. [CrossRef] [PubMed]

46. Aggarwal, B.B.; Sundaram, C.; Prasad, S.; Kannappan, R. Tocotrienols, the vitamin E of the 21st century: Its potential against cancer and other chronic diseases. Biochem. Pharmacol. 2010, 80, 1613-1631. [CrossRef] [PubMed]

47. Wong, S.K.; Chin, K.Y.; Suhaimi, F.H.; Ahmad, F.; Ima-Nirwana, S. Vitamin E As a Potential Interventional Treatment for Metabolic Syndrome: Evidence from Animal and Human Studies. Front. Pharmacol. 2017, 8 , 444. [CrossRef] [PubMed]

48. Freedman, J.E.; Keaney, J.F., Jr. Vitamin E inhibition of platelet aggregation is independent of antioxidant activity. J. Nutr. 2001, 131, 374s-377s. [CrossRef] [PubMed]

49. Lobo, V.; Patil, A.; Phatak, A.; Chandra, N. Free radicals, antioxidants and functional foods: Impact on human health. Pharmacogn. Rev. 2010, 4, 118-126. [CrossRef] [PubMed]

50. Shukla, A.; Rasik, A.M.; Patnaik, G.K. Depletion of reduced glutathione, ascorbic acid, vitamin E and antioxidant defence enzymes in a healing cutaneous wound. Free Radic. Res. 1997, 26, 93-101. [CrossRef] [PubMed]

51. Lin, T.S.; Latiff, A.A.; Hamid, N.A.A.; Ngah, W.Z.b.W.; Mazlan, M. Evaluation of topical tocopherol cream on cutaneous wound healing in streptozotocin-induced diabetic rats. Evid. Based Complement. Altern. Med. 2012, 2012, 491027. [CrossRef] [PubMed]

52. Musalmah, M.; Nizrana, M.Y.; Fairuz, A.H.; NoorAini, A.H.; Azian, A.L.; Gapor, M.T.; Wan Ngah, W.Z. Comparative effects of palm vitamin $\mathrm{E}$ and alpha-tocopherol on healing and wound tissue antioxidant enzyme levels in diabetic rats. Lipids 2005, 40, 575-580. [CrossRef] [PubMed]

53. Shin, J.; Yang, S.J.; Lim, Y. Gamma-tocopherol supplementation ameliorated hyper-inflammatory response during the early cutaneous wound healing in alloxan-induced diabetic mice. Exp. Biol. Med. 2017, 242, 505-515. [CrossRef] [PubMed]

54. Musalmah, M.; Fairuz, A.H.; Gapor, M.T.; Ngah, W.Z. Effect of vitamin E on plasma malondialdehyde, antioxidant enzyme levels and the rates of wound closures during wound healing in normal and diabetic rats. Asia Pac. J. Clin. Nutr. 2002, 11 (Suppl. 7), S448-S451. [CrossRef] [PubMed]

55. Xu, C.; Bentinger, M.; Savu, O.; Moshfegh, A.; Sunkari, V.; Dallner, G.; Swiezewska, E.; Catrina, S.B.; Brismar, K.; Tekle, M. Mono-epoxy-tocotrienol-alpha enhances wound healing in diabetic mice and stimulates in vitro angiogenesis and cell migration. J. Diabetes Complicat. 2017, 31, 4-12. [CrossRef] [PubMed]

56. Simon, G.A.; Schmid, P.; Reifenrath, W.G.; van Ravenswaay, T.; Stuck, B.E. Wound healing after laser injury to skin-The effect of occlusion and vitamin E. J. Pharm. Sci. 1994, 83, 1101-1106. [CrossRef] [PubMed]

57. Hu, H.; Tang, Y.; Pang, L.; Lin, C.; Huang, W.; Wang, D.; Jia, W. Angiogenesis and Full-Thickness Wound Healing Efficiency of a Copper-Doped Borate Bioactive Glass/Poly(lactic- co-glycolic acid) Dressing Loaded with Vitamin E in Vivo and in Vitro. ACS Appl. Mater. Interfaces 2018, 10, 22939-22950. [CrossRef] [PubMed]

58. Galeano, M.; Torre, V.; Deodato, B.; Campo, G.M.; Colonna, M.; Sturiale, A.; Squadrito, F.; Cavallari, V.; Cucinotta, D.; Buemi, M.; et al. Raxofelast, a hydrophilic vitamin E-like antioxidant, stimulates wound healing in genetically diabetic mice. Surgery 2001, 129, 467-477. [PubMed]

59. Magalhaes, M.S.; Fechine, F.V.; Macedo, R.N.; Monteiro, D.L.; Oliveira, C.C.; Brito, G.A.; Moraes, M.E.; Moraes, M.O. Effect of a combination of medium chain triglycerides, linoleic acid, soy lecithin and vitamins A and $\mathrm{E}$ on wound healing in rats. Acta Cir. Bras. 2008, 23, 262-269. [CrossRef] [PubMed]

60. Barbosa, E.; Faintuch, J.; Machado Moreira, E.A.; Gonçalves da Silva, V.R.; Lopes Pereima, M.J.; Martins Fagundes, R.L.; Filho, D.W. Supplementation of vitamin E, vitamin C, and zinc attenuates oxidative stress in burned children: A randomized, double-blind, placebo-controlled pilot study. J. Burn Care Res. 2009, 30, 859-866. [CrossRef] [PubMed] 
61. Zampieri, N.; Zuin, V.; Burro, R.; Ottolenghi, A.; Camoglio, F.S. A prospective study in children: Pre- and post-surgery use of vitamin E in surgical incisions. J. Plast. Reconstr. Aesthet. Surg. 2010, 63, 1474-1478. [CrossRef] [PubMed]

62. Stanizzi, A.; Bottoni, M.; Tartaglione, C.; Bolletta, E.; Benedetto, G.D. Associated use of silicone-vitamin E gauzes and alpha-tocopherol acetate oil in healing of skin graft donor sites. Int. Wound J. 2017, 14, 813-817. [CrossRef] [PubMed]

63. Khoo, T.L.; Halim, A.S.; Zakaria, Z.; Mat Saad, A.Z.; Wu, L.Y.; Lau, H.Y. A prospective, randomised, double-blinded trial to study the efficacy of topical tocotrienol in the prevention of hypertrophic scars. J. Plast. Reconstr. Aesthet. Surg. 2011, 64, e137-e145. [CrossRef] [PubMed]

64. Baumann, L.S.; Spencer, J. The effects of topical vitamin E on the cosmetic appearance of scars. Dermatol. Surg. 1999, 25, 311-315. [CrossRef] [PubMed]

65. Mittal, M.; Siddiqui, M.R.; Tran, K.; Reddy, S.P.; Malik, A.B. Reactive Oxygen Species in Inflammation and Tissue Injury. Antioxid. Redox Signal. 2014, 20, 1126-1167. [CrossRef] [PubMed]

66. Pierpaoli, E.; Orlando, F.; Cirioni, O.; Simonetti, O.; Giacometti, A.; Provinciali, M. Supplementation with tocotrienols from Bixa orellana improves the in vivo efficacy of daptomycin against methicillin-resistant Staphylococcus aureus in a mouse model of infected wound. Phytomedicine 2017, 36, 50-53. [CrossRef] [PubMed]

67. Provinciali, M.; Cirioni, O.; Orlando, F.; Pierpaoli, E.; Barucca, A.; Silvestri, C.; Ghiselli, R.; Scalise, A.; Brescini, L.; Guerrieri, M.; et al. Vitamin E improves the in vivo efficacy of tigecycline and daptomycin in an animal model of wounds infected with meticillin-resistant Staphylococcus aureus. J. Med. Microbiol. 2011, 60 Pt 12, 1806-1812. [CrossRef]

68. Ramli, N.Z.; Chin, K.Y.; Zarkasi, K.A.; Ahmad, F. A Review on the Protective Effects of Honey against Metabolic Syndrome. Nutrients 2018, 10, 1009. [CrossRef] [PubMed]

69. Buba, F.; Gidado, A.; Shugaba, A. Analysis of biochemical composition of honey samples from North-East Nigeria. Biochem. Anal. Biochem. 2013, 2, 1-7.

70. White, J.; Doner, L.W. Honey composition and properties. Beekeep. U. S. Agric. Handb. 1980, 335, 82-91.

71. Haryanto, H.; Urai, T.; Mukai, K.; Gontijo Filho, P.P.; Suriadi, S.; Sugama, J.; Nakatani, T. Effectiveness of indonesian honey on the acceleration of cutaneous wound healing: An experimental study in mice. Wounds 2012, 24, 110-119. [PubMed]

72. Paydar, S.; Akrami, M.; Dehghanian, A.; Moghadam, R.A.; Heidarpour, M.; Khoob, A.B.; Dalfardi, B. A Comparison of the Effects of Alpha and Medical-Grade Honey Ointments on Cutaneous Wound Healing in Rats. J. Pharm. 2016, 2016, 9613908. [CrossRef] [PubMed]

73. Khoo, Y.T.; Halim, A.S.; Singh, K.K.; Mohamad, N.A. Wound contraction effects and antibacterial properties of Tualang honey on full-thickness burn wounds in rats in comparison to hydrofibre. BMC Complement. Altern. Med. 2010, 10, 48. [CrossRef] [PubMed]

74. Nakajima, Y.; Nakano, Y.; Fuwano, S.; Hayashi, N.; Hiratoko, Y.; Kinoshita, A.; Miyahara, M.; Mochizuki, T.; Nishino, K.; Tsuruhara, Y.; et al. Effects of three types of Japanese honey on full-thickness wound in mice. Evid. Based Complement. Altern. Med. 2013, 2013, 504537. [CrossRef] [PubMed]

75. Mukai, K.; Nakano, Y.; Fuwano, S.; Hayashi, N.; Hiratoko, Y.; Kinoshita, A.; Miyahara, M.; Mochizuki, T.; Nishino, K.; Tsuruhara, Y.; et al. Evaluation of the effects of a combination of Japanese honey and hydrocolloid dressing on cutaneous wound healing in male mice. Evid. Based Complement. Altern. Med. 2015, 2015, 910605. [CrossRef] [PubMed]

76. Vijaya, K.K.; Nishteswar, K. Wound healing activity of honey: A pilot study. Ayu 2012, 33, 374-377. [PubMed]

77. Nikpour, M.; Shirvani, M.A.; Azadbakht, M.; Zanjani, R.; Mousavi, E. The effect of honey gel on abdominal wound healing in cesarean section: A triple blind randomized clinical trial. Oman Med. J. 2014, 29, 255-259. [CrossRef] [PubMed]

78. Lavaf, M.; Simbar, M.; Mojab, F.; Alavi Majd, H.; Samimi, M. Comparison of honey and phenytoin (PHT) cream effects on intensity of pain and episiotomy wound healing in nulliparous women. J. Complement. Integr. Med. 2017, 15. [CrossRef] [PubMed]

79. Lund-Nielsen, B.; Adamsen, L.; Kolmos, H.J.; Rørth, M.; Tolver, A.; Gottrup, F. The effect of honey-coated bandages compared with silver-coated bandages on treatment of malignant wounds-a randomized study. Wound Repair Regen. 2011, 19, 664-670. [CrossRef] [PubMed] 
80. Goharshenasan, P.; Amini, S.; Atria, A.; Abtahi, H.; Khorasani, G. Topical Application of Honey on Surgical Wounds: A Randomized Clinical Trial. Forsch. Komplementmed. 2016, 23, 12-15. [CrossRef] [PubMed]

81. Nasir, N.A.; Halim, A.S.; Singh, K.K.; Dorai, A.A.; Haneef, M.N. Antibacterial properties of tualang honey and its effect in burn wound management: A comparative study. BMC Complement. Altern. Med. 2010, 10, 31. [CrossRef] [PubMed]

82. Maghsoudi, H.; Salehi, F.; Khosrowshahi, M.K.; Baghaei, M.; Nasirzadeh, M.; Shams, R. Comparison between topical honey and mafenide acetate in treatment of burn wounds. Ann. Burns Fire Disasters 2011, 24, 132-137. [PubMed]

83. Baghel, P.S.; Shukla, S.; Mathur, R.K.; Randa, R. A comparative study to evaluate the effect of honey dressing and silver sulfadiazene dressing on wound healing in burn patients. Indian J. Plast. Surg. 2009, 42, 176-181. [CrossRef] [PubMed]

84. Gupta, S.S.; Singh, O.; Bhagel, P.S.; Moses, S.; Shukla, S.; Mathur, R.K. Honey dressing versus silver sulfadiazene dressing for wound healing in burn patients: A retrospective study. J. Cutan. Aesthet. Surg. 2011, 4, 183-187. [CrossRef] [PubMed]

85. Mandal, M.D.; Mandal, S. Honey: Its medicinal property and antibacterial activity. Asian Pac. J. Trop. Biomed. 2011, 1, 154-160. [CrossRef]

86. Gannabathula, S.; Skinner, M.A.; Rosendale, D.; Greenwood, J.M.; Mutukumira, A.N.; Steinhorn, G.; Stephens, J.; Krissansen, G.W.; Schlothauer, R.C. Arabinogalactan proteins contribute to the immunostimulatory properties of New Zealand honeys. Immunopharmacol. Immunotoxicol. 2012, 34, 598-607. [CrossRef] [PubMed]

87. Tonks, A.J.; Cooper, R.A.; Jones, K.P.; Blair, S.; Parton, J.; Tonks, A. Honey stimulates inflammatory cytokine production from monocytes. Cytokine 2003, 21, 242-247. [CrossRef]

88. Hussein, S.Z.; Mohd Yusoff, K.; Makpol, S.; Mohd Yusof, Y.A. Gelam honey attenuates carrageenan-induced rat paw inflammation via NF-kappaB pathway. PLoS ONE 2013, 8, e72365. [CrossRef] [PubMed]

89. Sell, S.A.; Wolfe, P.S.; Spence, A.J.; Rodriguez, I.A.; McCool, J.M.; Petrella, R.L.; Garg, K.; Ericksen, J.J.; Bowlin, G.L. A Preliminary Study on the Potential of Manuka Honey and Platelet-Rich Plasma in Wound Healing. Int. J. Biomater. 2012, 2012, 313781. [CrossRef] [PubMed]

90. Almasaudi, S.B.; El-Shitany, N.A.; Abbas, A.T.; Abdel-dayem, U.A.; Ali, S.S.; Al Jaouni, S.K.; Harakeh, S. Antioxidant, Anti-inflammatory, and Antiulcer Potential of Manuka Honey against Gastric Ulcer in Rats. Oxid. Med. Cell. Longev. 2016, 2016, 3643824. [CrossRef] [PubMed]

91. Dixon, B. Bacteria can't resist honey. Lancet Infect. Dis. 2003, 3, 116. [CrossRef]

92. Oryan, A.; Alemzadeh, E.; Moshiri, A. Biological properties and therapeutic activities of honey in wound healing: A narrative review and meta-analysis. J. Tissue Viability 2016, 25, 98-118. [CrossRef] [PubMed]

93. Giusto, G.; Vercelli, C.; Comino, F.; Caramello, V.; Tursi, M.; Gandini, M. A new, easy-to-make pectin-honey hydrogel enhances wound healing in rats. BMC Complement. Altern. Med. 2017, 17, 266. [CrossRef] [PubMed]

94. Alizadeh, A.M.; Sohanaki, H.; Khaniki, M.; Mohaghgheghi, M.A.; Ghmami, G.; Mosavi, M. The effect of teucrium polium honey on the wound healing and tensile strength in rat. Iran. J. Basic Med. Sci. 2011, 14, 499-505. [PubMed]

95. Iftikhar, F.; Arshad, M.; Rasheed, F.; Amraiz, D.; Anwar, P.; Gulfraz, M. Effects of acacia honey on wound healing in various rat models. Phytother. Res. 2010, 24, 583-586. [CrossRef] [PubMed]

96. Sazegar, G.; Seyed Reza, A.H.; Behravan, E. The effects of supplemental zinc and honey on wound healing in rats. Iran. J. Basic Med. Sci. 2011, 14, 391-398. [PubMed]

97. Kundu, S.; Biswas, T.K.; Das, P.; Kumar, S.; De, D.K. Turmeric (Curcuma longa) rhizome paste and honey show similar wound healing potential: A preclinical study in rabbits. Int. J. Low. Extrem. Wounds 2005, 4, 205-213. [CrossRef] [PubMed]

98. Nisbet, H.O.; Nisbet, C.; Yarim, M.; Guler, A.; Ozak, A. Effects of three types of honey on cutaneous wound healing. Wounds 2010, 22, 275-283. [PubMed]

99. Medeiros Vde, F.; Azevedo, Í.M.; Rêgo, A.C.; Egito, E.S.; Araújo-Filho, I.; Medeiros, A.C. Antibacterial properties and healing effects of Melipona scutellaris honey in MRSA-infected wounds of rats. Acta Cir. Bras. 2016, 31, 327-332. [CrossRef] [PubMed] 
100. Tsang, A.S.; Dart, A.J.; Sole-Guitart, A.; Dart, C.M.; Perkins, N.R.; Jeffcott, L.B. Comparison of the effects of topical application of UMF20 and UMF5 manuka honey with a generic multifloral honey on wound healing variables in an uncontaminated surgical equine distal limb wound model. Aust. Vet. J. 2017, 95, 333-337. [CrossRef] [PubMed]

101. Takzaree, N.; Hassanzadeh, G.; Rouini, M.R.; Manayi, A.; Hadjiakhondi, A.; Majidi Zolbin, M. Evaluation of the Effects of Local Application of Thyme Honey in Open Cutaneous Wound Healing. Iran. J. Public Health 2017, 46, 545-551. [PubMed]

102. Takzaree, N.; Hadjiakhondi, A.; Hassanzadeh, G.; Rouini, M.R.; Manayi, A. Synergistic Effect of Honey and Propolis on Cutaneous Wound Healing in Rats. Acta Med. Iran. 2016, 54, 233-239. [PubMed]

103. Farzadinia, P.; Jofreh, N.; Khatamsaz, S.; Movahed, A.; Akbarzadeh, S.; Mohammadi, M.; Bargahi, A. Anti-inflammatory and Wound Healing Activities of Aloe vera, Honey and Milk Ointment on Second-Degree Burns in Rats. Int. J. Low. Extrem. Wounds 2016, 15, 241-247. [CrossRef] [PubMed]

104. Schencke, C.; Vasconcellos, A.; Sandoval, C.; Torres, P.; Acevedo, F.; del Sol, M. Morphometric evaluation of wound healing in burns treated with Ulmo (Eucryphia cordifolia) honey alone and supplemented with ascorbic acid in guinea pig (Cavia porcellus). Burns Trauma 2016, 4, 25. [CrossRef] [PubMed]

105. Sukur, S.M.; Halim, A.S.; Singh, K.K. Evaluations of bacterial contaminated full thickness burn wound healing in Sprague Dawley rats Treated with Tualang honey. Indian J. Plast. Surg. 2011, 44, 112-117. [PubMed]

106. Conand, C. The Fishery Resources of Pacific Island Countries. Part 2 Holothurians (Fisheries Technical Paper No. 272.2); Food and Agriculture Organisation: Rome, Italy, 1990.

107. Fell, H.B. Phylum Echinodermata. In Textbook of Zoology: Invertebrates; Marshall, A.J., Williams, W.D., Eds.; Macmillan Education UK: London, UK, 1972; pp. 776-837.

108. Huizeng, F. Sea cucumber: Ginseng of sea. Zhongguo Marine Med. 2001, 82, 37-44.

109. Taiyeb-Ali, T.B.; Zainuddin, S.L.; Swaminathan, D.; Yaacob, H. Efficacy of 'Gamadent' toothpaste on the healing of gingival tissues: A preliminary report. J. Oral Sci. 2003, 45, 153-159. [CrossRef] [PubMed]

110. Lu, Y.; Wang, B.L. The research progress of antitumorous effectiveness of Stichopus japonicus acid mucopolysaccharide in north of China. Am. J. Med. Sci. 2009, 337, 195-198. [CrossRef] [PubMed]

111. Kamarudin, K.R. An update on diversity of sea cucumber (Echinodermata: Holothuroidea) in Malaysia. Malay. Nat. J. 2010, 62, 315-334.

112. Manan, W.Z.W.; Mahalingam, S.R.; Arshad, K.; Bukhari, S.I.; Ming, L.C. Safety and efficacy of sea cucumber containing products. Arch. Pharm. Pract. 2016, 7, 48-52.

113. Kerr, R.G.; Chen, Z. In vivo and in vitro biosynthesis of saponins in sea cucumbers. J. Nat. Prod. 1995, 58, 172-176. [CrossRef] [PubMed]

114. Vieira, R.P.; Pedrosa, C.; Mourao, P.A. Extensive heterogeneity of proteoglycans bearing fucose-branched chondroitin sulfate extracted from the connective tissue of sea cucumber. Biochemistry 1993, 32, 2254-2262. [CrossRef] [PubMed]

115. Pacheco, R.G.; Vicente, C.P.; Zancan, P.; Mourão, P.A. Different antithrombotic mechanisms among glycosaminoglycans revealed with a new fucosylated chondroitin sulfate from an echinoderm. Blood Coagul. Fibrinolysis 2000, 11, 563-573. [CrossRef] [PubMed]

116. Mourao, P.A.; Boisson-Vidal, C.; Tapon-Bretaudière, J.; Drouet, B.; Bros, A.; Fischer, A. Inactivation of thrombin by a fucosylated chondroitin sulfate from echinoderm. Thromb. Res. 2001, 102, 167-176. [CrossRef]

117. Goad, L.J.; Garneau, F.-X.; Simard, J.-L.; ApSimon, J.W.; Girard, M. Isolation of $\Delta 9$ (11)-sterols from the sea cucumber psolusfabricii. Implications for holothurin biosynthesis. Tetrahedron Lett. 1985, 26, 3513-3516. [CrossRef]

118. Mamelona, J.; Pelletier, E.; Girard-Lalancette, K.; Legault, J.; Karboune, S.; Kermasha, S. Quantification of phenolic contents and antioxidant capacity of Atlantic sea cucumber, Cucumaria frondosa. Food Chem. 2007, 104, 1040-1047. [CrossRef]

119. Ahmed, M.R.; Venkateshwarlu, U.; Jayakumar, R. Multilayered peptide incorporated collagen tubules for peripheral nerve repair. Biomaterials 2004, 25, 2585-2594. [CrossRef] [PubMed]

120. Sugawara, T.; Zaima, N.; Yamamoto, A.; Sakai, S.; Noguchi, R.; Hirata, T. Isolation of sphingoid bases of sea cucumber cerebrosides and their cytotoxicity against human colon cancer cells. Biosci. Biotechnol. Biochem. 2006, 70, 2906-2912. [CrossRef] [PubMed]

121. Mojica, E.-R.E.; Merca, F.E. Organs of the Sea Cucumber (Holothuria scabra Jaeger). Int. J. Zool. Res. 2005, 1, 59-65. 
122. Ridzwan, B. Sea cucumbers, a Malaysian heritage. Research Centre of International Islamic University Malaysia (IIUM); Kuala Lumpur Wilayah Persekutuan: Kuala Lumpur, Malaysia, 2007.

123. Ming, S. Investigation on Component and Pharmacology of Sea Cucumber. Chin. Tradit. Pat. Med. 2001, 10, 21.

124. Masre, S.F.; Yip, G.W.; Sirajudeen, K.N.S.; Ghazali, F.C. Wound healing activity of total sulfated glycosaminoglycan (GAG) from Stichopus vastus and Stichopus hermanni integumental tissue in rats. Int. J. Mol. Med. 2010, 6, 49-53. [CrossRef]

125. Subramaniam, B.S.; Amuthan, A.; D'Almeida, P.M.; Arunkumar, H.D. Efficacy of gamat extract in wound healing in albino wistar rats. Int. J. Pharm. Sci. Rev. Res. 2013, 20, 142-145.

126. Mazliadiyana, M.; Nazrun, A.; Isa, N. Optimum Dose of Sea Cucumber (Stichopus Chloronotus) Extract for Wound Healing. Med. Health 2017, 12, 83-89.

127. Zohdi, R.M.; Zakaria, Z.A.; Yusof, N.; Mustapha, N.M.; Abdullah, M.N. Sea cucumber (Stichopus hermanii) based hydrogel to treat burn wounds in rats. J. Biomed. Mater. Res. B Appl. Biomater. 2011, 98, 30-37. [CrossRef] [PubMed]

128. Gupta, S.; Lawrence, W.T. Wound healing: Normal and abnormal mechanisms and closure techniques. The Physiologic Basis for Surgery, 4th ed.; Lippincott Williams \& Wilkins: Philadelphia, PA, USA, 2008.

129. Althunibat, O.Y.; Hashim, R.B.; Taher, M.; Daud, J.M.; Ikeda, M.-A.; Zali, B.I. In vitro antioxidant and antiproliferative activities of three Malaysian sea cucumber species. Eur. J. Sci. Res. 2009, 37, 376-387.

130. Fredalina, B.D.; Ridzwan, B.H.; Abidin, A.A.; Kaswandi, M.A.; Zaiton, H.; Zali, I.; Kittakoop, P.; Jais, A.M. Fatty acid compositions in local sea cucumber, Stichopus chloronotus, for wound healing. Gen. Pharmacol. 1999, 33, 337-340. [CrossRef]

131. Werner, S.; Grose, R. Regulation of wound healing by growth factors and cytokines. Physiol. Rev. 2003, 83, 835-870. [CrossRef] [PubMed]

132. Efron, P.A.; Moldawer, L.L. Cytokines and wound healing: The role of cytokine and anticytokine therapy in the repair response. J. Burn Care Rehabil. 2004, 25, 149-160. [CrossRef] [PubMed]

133. Mariana, N.S.; Nik, K.A.N.I.; Neela, V.K.; Norfarrah, M.A.; Sekawi, Z. In vivo evaluation on Malaysian coastal isolates of Gracilaria changii and Stichopus badionotus through heat-burn methicillin-resistant Staphylococcus aureus (MRSA) infection animal model. Afr. J. Microbiol. Res. 2011, 5, 1379-1382. [CrossRef]

134. Arundina, I.; Yuliati, Y.; Soesilawati, P.; Damaiyanti, D.W.; Maharani, D. The effects of golden sea cucumber extract (Stichopus hermanii) on the number of lymphocytes during the healing process of traumatic ulcer on wistar rat's oral mucous. Dent. J. (Maj. Kedokt. Gigi) 2015, 48, 100-103. [CrossRef]

135. Peakman, M.; Vergani, D. Basic and Clinical Immunology; Churchill Livingstone: London, UK, 2009.

136. Haryanto, H.; Ogai, K.; Suriadi, S.; Nakagami, G.; Oe, M.; Nakatani, T.; Okuwa, M.; Sanada, H.; Sugama, J. A prospective observational study using sea cucumber and honey as topical therapy for diabetic foot ulcers in Indonesia. J. Wellness Health Care 2017, 41, 41-56.

137. El Barky, A.; Ali, E.; Mohamed, T. Marine sea cucumber saponins and diabetes. Austin Pancreat. Disord. 2017, 1, 1002.

138. Calder, P.C. Omega-3 Fatty Acids and Inflammatory Processes. Nutrients 2010, 2, 355-374. [CrossRef] [PubMed]

139. Hawa, I., Jr.; Zulaikah, M.; Jamaludin, M.; Zainal Abidin, A.; Kaswandi, M.; Ridzwan, B. The potential of the coelomic fluid in sea cucumber as an antioxidant. Malays. J. Nutr. 1999, 5, 55-59. [PubMed]

140. Johnson, N.R.; Wang, Y. Drug delivery systems for wound healing. Curr. Pharm. Biotechnol. 2015, 16, 621-629. [CrossRef] [PubMed]

141. Sarabahi, S. Recent advances in topical wound care. Indian J. Plast. Surg. Off. Publ. Assoc. Plast. Surg. India 2012, 45, 379-387. [CrossRef] [PubMed]

(C) 2018 by the authors. Licensee MDPI, Basel, Switzerland. This article is an open access article distributed under the terms and conditions of the Creative Commons Attribution (CC BY) license (http:/ / creativecommons.org/licenses/by/4.0/). 